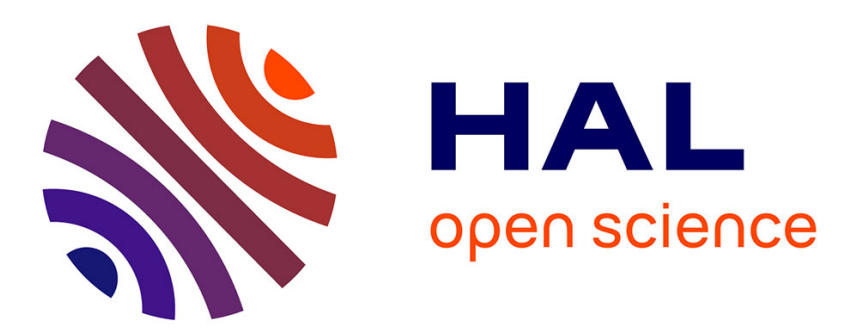

\title{
Fish remains (Elasmobranchii, Actinopterygii) from the Late Cretaceous of the Benue Trough, Nigeria
}

\author{
Romain Vullo, Philippe Courville
}

\section{To cite this version:}

Romain Vullo, Philippe Courville. Fish remains (Elasmobranchii, Actinopterygii) from the Late Cretaceous of the Benue Trough, Nigeria. Journal of African Earth Sciences, 2014, 97, pp.194-206. 10.1016/j.jafrearsci.2014.04.016 . insu-01004270

HAL Id: insu-01004270

https://hal-insu.archives-ouvertes.fr/insu-01004270

Submitted on 11 Jun 2014

HAL is a multi-disciplinary open access archive for the deposit and dissemination of scientific research documents, whether they are published or not. The documents may come from teaching and research institutions in France or abroad, or from public or private research centers.
L'archive ouverte pluridisciplinaire HAL, est destinée au dépôt et à la diffusion de documents scientifiques de niveau recherche, publiés ou non, émanant des établissements d'enseignement et de recherche français ou étrangers, des laboratoires publics ou privés. 
1 Fish remains (Elasmobranchii, Actinopterygii) from the Late Cretaceous of

2 the Benue Trough, Nigeria

\section{Romain Vullo *, Philippe Courville}

5 Laboratoire Géosciences Rennes, UMR CNRS 6118, Université de Rennes 1, 263

6 avenue du Général Leclerc, 35042, Rennes, France

7

$8 *$ corresponding author.

$9 \quad$ Email address: romain.vullo@univ-rennes1.fr

11 Abstract

12 Selachian and ray-finned fish remains from various Late Cretaceous localities of

13 Nigeria are described. Each locality has yielded only a very few specimens and the

14 diversity is therefore very low. However, some taxa are recorded for the first time in

15 Africa. The Ashaka locality in the Upper Benue Trough (northeastern Nigeria) has

16 yielded a small but interesting late Cenomanian assemblage of microremains, including

17 teeth of "Carcharias" amonensis, Rhombopterygia zaborskii sp. nov., Hamrabatis sp.,

18 "Stephanodus" sp., and a possible ionoscopiform. A large prearticular dentition coming

19 from the early Turonian beds of this locality is assigned to the large pycnodontiform

20 Acrotemnus, a poorly known genus here regarded as a senior synonym of

21 Macropycnodon. In the Lower Benue Trough (southeastern Nigeria), several localities

22 ranging in age from the late Cenomanian to the early Maastrichtian have yielded various

23 widespread taxa such as Ptychodus, Scapanorhynchus, Squalicorax, Vidalamiinae

24 indet., cf. Protosphyraena, and Eodiaphyodus. The seaway that occupied the Benue 
25 Trough during transgressive episodes (late Cenomanian-early Turonian and

26 Maastrichtian) created opportunities for the dispersal of many marine fish taxa into new 27 areas, such as the proto-South Atlantic.

28

Keywords: Elasmobranchii; Actinopterygii; Late Cretaceous; Benue Trough; Nigeria.

\section{Introduction}

Late Cretaceous fish faunas from Africa are relatively well known (see López-

Arbarello, 2004 and Murray, 2000 for a review). In Nigeria, most of the works have dealt with Paleogene material (Odunze et al., 2009, 2012; Stevens et al., 2011; White, 1926, 1934, 1955) whereas only a very few Cretaceous specimens have been reported.

38 Woods (1911) mentioned the presence of Gigantichthys (= Onchosaurus) sp. in the

39 Turonian of Kumberi (northern part of the Middle Benue Trough) on the basis of some

40 remains collected by J.D. Falconer and A. Longbottom and identified by A.S.

41 Woodward.

42 White (1934) described some fish remains coming from the southern part of the

43 Iullemmeden Basin (Gilbedi and Kaffe localities, Sokoto State, northwestern Nigeria).

44 On the basis of this material, all Maastrichtian in age, White (1934) identified the

45 following taxa: Lamna appendiculata var. biauriculata (= Cretolamna biauriculata),

46 Lamna libyca (= Serratolamna serrata), Schizorhiza stromeri, ?Pristinae indet.,

47 Stephanodus libycus, and Pycnodontidae indet., besides "selachian vertebrae and

48 remains of indeterminable bony fishes". This assemblage was later assigned by Kogbe 
49 (1974) to the Maastrichtian Dukamaje Formation.

50 Carter et al. (1963) provided two lists of fish taxa collected from two localities in

51 northeastern Nigeria and identified by E.I. White. The first list (i.e., Onchosaurus

52 pharao, Schizorhiza stromeri, Enchodus cf. lamberti, Ceratodus sp., Lamna sp.)

53 corresponds to a fish assemblage collected from a section in the Biriji River, near

54 Gombe, exposing the base of the Yolde Formation (Cenomanian in age). The second list

55 (i.e., Schizorhiza stromeri, ?Stratodus apicalis, Lamna? serrata, Enchodus lamberti)

56 indicates the fish taxa obtained from a well sunk into the Fika Shales Formation

57 (Turonian?-Coniacian to Santonian-Campanian? in age) at Damagum. The Fika Shales

58 are a clay sedimentary unit occurring in the most northwestern part of the Upper Benue

59 Trough, partly equivalent to the Pindiga Formation. It is worth noting that the known

60 stratigraphical range of some of these species is not consistent with the age of the

61 involved formations, thus suggesting possible misidentifications or sampling bias.

62 Unfortunately, the current whereabouts of the fish material reported by Carter et al.

63 (1963) is unknown and we were unable to re-examine these specimens. The section in

64 the Biriji River near Gombe was visited by one of us (P.C.) in 1990; the outcrops

65 occurring by that time were of variable quality, and it was not possible to obtain further

66 material. Similarly, no good outcrops or fossils were recently obtained from the Fika

67 Shales, despite numerous field observations by one of us (P.C.) in 1990.

68 Lastly, in a study on ammonites from the Ashaka quarry, Courville (1992: 314)

69 noted the presence of various, well-preserved remains of fishes (selachians, pycnodonts)

70 in three distinct stratigraphical levels; these specimens are described in the present work

71 (see below). In a paper dealing with foraminifera from the same quarry, Gebhardt

72 (1997) also mentioned the occurrence of fish remains in several beds of this section, late 
73 Cenomanian to early Turonian in age.

74 The material studied in the present work represents the first marine fish remains

75 from the Benue Trough that are well constrained stratigraphically and geographically.

76 All of them were collected by one of us (P.C.) from 1989 to 1991 during field

77 prospections. This material was obtained by surface collecting, except microteeth from

78 one peculiar level of the Ashaka quarry, obtained by screen washing (see below).

\section{Geographical and geological settings}

82
In Nigeria, West Africa (Fig. 1A1), the Cretaceous marine formations mainly extend in the eastern part of the country, alongside the Benue River and southern branch of the Niger River. The Benue Trough corresponds to a multiple SW-NE strike-slip basin, which origin is directly related to the Early Cretaceous South Atlantic opening (Benkhelil, 1988, 1989; Guiraud, 1991). Its geographical location is particularly interesting, as: 1) being opened to the Cretaceous oceanic domain (modern Calabar flank; Fig. 1A2); 2) a link to the Saharan areas of northeastern Nigeria (Chad Basin; Fig. 1A2), episodically opened to the Late Cretaceous trans-Saharan seaway related itself to the southern margin of the Tethyan Ocean (Courville, 1993; Courville et al., 1998; Reyment and Dingle, 1987).

The Nigerian Late Cretaceous formations and faunas (mainly ammonites and other invertebrates) from the Benue Trough (northern part: Upper Benue Trough; southern part: Lower Benue Trough) have been studied for long (e.g., Barber, 1958; Carter et al., 1963; Reyment, 1955; Woods, 1911). More recently, the main marine 
97 sedimentary units of the Benue Trough have been studied with a particular

98 biostratigraphical and palaeobiological consideration (e.g., Meister, 1989; Zaborski,

$991983,1987,1990 a)$. A synthesis of the historical and original data was realized by

100 Courville (1993).

101 In northeastern Nigeria, marine conditions partly occurred during the latest

102 Cenomanian-latest "Senonian" (Campanian-Maastrichtian?) interval; only one main

103 clay-shale-dominated sedimentary unit including basal limestone beds (Pindiga

104 Formation and equivalents; Fig. 1B2), occurs. Further south, marine conditions started

105 earlier and earlier (early Albian around the Niger Delta), and persisted continuously

106 during Late Cretaceous times; several local thick clay-shale formations are piling up

107 (Fig. 1B1).

108 From the Chad Basin part of the Upper Benue Trough (Fig. 1B2), quite

109 numerous fish remains were obtained from the Gongila Formation (partly equivalent to

110 the Pindiga Formation), at the classic section of the Ashaka quarry (levels $9>, 21>$ and

11126 in Courville, 1992: fig. 3). The level 9> corresponds to a marly sediment including

112 an important sandy fraction and numerous phosphatized elements (mainly fish debris).

113 A few teeth were obtained by screen washing (using 0.5 and $1 \mathrm{~mm}$ mesh-sized sieves)

114 of a small amount ( $\sim 50 \mathrm{~g})$ of matrix from this level. It is considered as latest

115 Cenomanian in age (Saharan Gadeni Zone, partly equivalent to the standard Juddii

116 Zone; Courville, 1993). From the marly-nodular limestone level 21>, vertebrate

117 remains are far less common and include several shark and bony fish teeth and

118 vertebrae, plus several unidentified bone fragments; this level is regarded as the younger

119 local Cenomanian horizon (same biozone as level 9>). Lastly, the level 26 (lowermost

120 Turonian: Saharan Flexuosum Zone $=$ Coloradoense Zone pars.) yielded only one large 
121

122

123

124

125

126

pycnodont dentition.

From the central part of the Upper Benue trough (Fig. 1B2), only poorlypreserved bones belonging to unidentifiable fishes or reptiles were collected from various latest Cenomanian to middle Turonian limestone beds (for outcrop details, see Zaborski, 1990a).

All other fish remains studied here were collected in southern Nigeria, from various formations and palaeogeographic areas (Fig. 1B1):

- The latest Cenomanian to early middle Turonian clay-shale series with nodular limestone beds of the Eze Aku Group was exposed with good conditions in several outcrops along the expressway at Lokpanta, located at the Atlantic side of the Lower Benue Trough (for detailed location and study, see Zaborski, 1987). These outcrops yielded quite common and diverse vertebrate remains, often poorly preserved, including fish teeth, vertebrae, or partial skeletons, as well as reptile bones.

- In the overlying clay-shale Awgu Formation of the same area, only poor outcrops occurred by that time, closely located to the sites mentioned by Reyment (1956); probably latest Coniacian to early Santonian in age (no recent ammonite findings), this series yielded a few shark teeth and poorly-preserved reptile bones. Further north, in the southern part of the Lower Benue Trough, the Nkalagu Limestones [a northern equivalent to the basal Awgu Shales, which is clearly early Coniacian in age (Courville, 1993; Offodile and Reyment, 1977; Zaborski, 1990b)], yielded only one isolated fish tooth.

- In southern Nigeria, the younger Late Cretaceous series examined belong to the fine-detritic Nkporo Shales Formation. Various but very poorly preserved, 
145

146

147

148

149

150

151

154

155

156

157

158

159

160

161

162

163

164

165 Ptychodus decurrens Agassiz, 1838

166 (Fig. 2A)

167

168

\section{Systematic palaeontology}

\section{Class CHONDRICHTHYES Huxley, 1880}

Family PTYCHODONTIDAE Jaekel, 1898

Genus Ptychodus Agassiz, 1838

(Fig. 2A)

mostly unidentifiable vertebrate remains occur in its lower part nearly in each outcrop (P.C. pers. obs.). It is only in the most southern area that good outcrops still existed, studied in details by Zaborski (1983, 1985). Rich ammonite faunas clearly indicate that these fossil assemblages occur below and above the Campanian-Maastrichtian boundary; amongst quite diverse and well-preserved fossil assemblages including bivalves, gastropods and crustaceans, one shark tooth and one fish tooth plate were collected in the early Maastrichtian beds of the "fauna 13" fossil site, $42 \mathrm{~km}$ from Calabar (Zaborski, 1985: fig. 1).

Specimen repository. All the material studied in the present work is deposited in the collections of Géosciences Rennes (GR), Université de Rennes 1, France.

Incerti ordinis (?HYBODONTIFORMES Patterson, 1966)

Material examined. One tooth (GR/PC.1773). 
169 Age and locality. Early Turonian (Nodosoides Zone), Lokpanta (level 31), southeastern

$170 \quad$ Nigeria.

171

172 Description. The specimen corresponds to a perfectly preserved tooth. It is wider (12.5

$173 \mathrm{~mm})$ than long $(10 \mathrm{~mm})$. The crown is not very high and bears eight transverse, curved

174 ridges that are concave labially. These ridges nearly reach the lateral margins of the

175 crown, where they can bifurcate. The narrow, rectangular marginal area of the crown

176 shows a granular surface, with short, irregular, anastomosed folds. The anaulacorhizous

177 root is relatively low and shows a weak basal concavity. A series of foramina is present

178 all around the specimen, just below the crown-root boundary. The root base is also

179 pierced by a few foramina.

180

181 Remarks. The morphology and features (e.g., small size, low crown, high number of

182 ridges) of this tooth allows its assignment to the globally widespread species Ptychodus

183 decurrens (see Verma et al., 2012). In Africa, this species was only reported from the

184 Cenomanian of Tunisia (Pervinquière, 1903) and late Turonian of Angola (Antunes and

185 Cappetta, 2002). Some teeth tentatively referred to $P$. decurrens were also reported

186 from the late Cenomanian-early Turonian black shales of Jbel Tselfat in Morocco

187 (Khalloufi et al., 2010).

188

190 Order LAMNIFORMES Berg, 1958

191 Family PSEUDOSCAPANORHYNCHIDAE Herman, 1979

192 Genus Protolamna Cappetta, 1980a 
194 cf. Protolamna sp.

195 (Fig. 2B)

196

197 Material examined. Three incomplete teeth (including GR/PC.1774).

198 Age and locality. Latest Cenomanian (Gadeni Zone), Ashaka quarry (level 21>),

199 northeastern Nigeria.

200

201

Description. The best preserved tooth shows an erect, narrow cusp bearing a few slight

202 lingual folds. The labial face is nearly flat whereas the lingual face is strongly convex in

203 apical view. The lingual protuberance of the root is well developed. Lateral cusplets and

204 root lobes are not preserved.

205

206

Remarks. Although these teeth are incomplete, the shape and ornamentation of the main

207 cusp combined to root morphology indicate that these specimens can be tentatively

208 assigned to the widespread Cretaceous genus Protolamna (Cappetta, 2012). In the other two pseudoscapanorhynchid genera Leptostyrax and Pseudoscapanorhynchus, the mesiodistal compression at the base of the labial face of the main cusp is stronger

211 (Cappetta, 2012). In Africa, teeth of Protolamna and Leptostyrax were reported from

212 the Albian of Angola and Tunisia (Antunes and Cappetta, 2002; Cuny et al., 2004).

215 Family OTODONTIDAE Glikman, 1964

216 
217 Genus Cretolamna Glikman, 1958

218

219 Cretolamna sp.

$220 \quad$ (Fig. 2C)

221

222 Material examined. One incomplete tooth (GR/PC.1775).

223 Age and locality. Coniacian?-Santonian, Awgu, southeastern Nigeria.

224

225 Description. The unique specimen corresponds to a large upper lateral tooth. The main

226 cusp bends distally and shows a convex mesial cutting edge. The distal cutting edge is

227 more rectilinear. Only the distal lateral cusplet is preserved. It is triangular, wider than

228 high, and relatively large. The root has a poorly marked lingual protuberance. The root

229 lobes are short and separated by a broad, rounded mediobasal notch.

230

231 Remarks. This tooth is very characteristic of this widespread genus. In Africa, teeth of

232 Cretolamna are common in Late Cretaceous marine deposits (e.g., Antunes and

233 Cappetta, 2002; Arambourg, 1952; Cuny et al., 2012; Dartevelle and Casier, 1949;

234 White, 1934). A lateral tooth with a similar morphology has been described as

235 Cretolamna appendiculata by Antunes and Cappetta (2002: pl. 10, fig. 12) from the late

236 Turonian of Iembe (Angola). Most of Cretolamna teeth found in Late Cretaceous

237 deposits have been commonly assigned to the type species $C$. appendiculata, but a

238 recent revision of this genus based on an abundant material from the Cenomanian-

239 Campanian interval shows that several species can be recognized among the $C$.

240 appendiculata group (Siverson et al., in press). 
243 Family ANACORACIDAE Casier, 1947

244 Genus Squalicorax Whitley, 1939

245

246 Squalicorax pristodontus (Agassiz, 1843)

247 (Fig. 2D)

248

249 Material examined. One incomplete tooth (GR/PC.1776).

250 Age and locality. Early Maastrichtian (Neubergicus Zone), Calabar, southeastern

251 Nigeria.

252

Description. This wide $(29 \mathrm{~mm})$, large tooth shows a rather gibbous mesial edge and an 254 attenuated distal heel. Serrations of the cutting edges are well developed. The basal part 255 of the root is not preserved.

256

257 Remarks. This widespread species is well known in the latest Cretaceous marine 258 deposits of Africa, especially in the Democratic Republic of the Congo (Dartevelle and 259 Casier, 1943), Morocco (Arambourg, 1952), Egypt (Cappetta, 1991; Gemmellaro, 260 1920), Angola (Antunes and Cappetta, 2002) and Senegal (Cuny et al., 2012).

263 Family MITSUKURINIDAE Jordan, 1898

264 Genus Scapanorhynchus Woodward, 1889 
266 Scapanorhynchus cf. texanus (Roemer, 1849)

267 (Fig. 2E, F)

268

269 Material examined. Three incomplete teeth (including GR/PC.1777, GR/PC.1778).

270 Age and locality. Coniacian?-Santonian, Awgu, southeastern Nigeria.

271

272 Description. These teeth are large (up to $41 \mathrm{~mm}$ in length) and relatively robust. The

273 crown consist of only one main cusp, without lateral cusplets. It is clearly sigmoid in

274 profile view. The lingual face is slightly convex and smooth whereas the labial face is

275 strongly convex and bears up to 25 well marked longitudinal folds. The root has a very

276 pronounced lingual protuberance marked by a short and deep groove. Only the distal

277 lobe of the root is preserved on the best preserved tooth (GR/PC.1777: Fig. 2E). It is

278 relatively robust and has a rounded extremity.

279

280 Remarks. The Nigerian specimens studied here are very similar to those figured by

281 Antunes and Cappetta (2002: pl. 9, fig. 4-7) from the late Turonian of Iembe (Angola).

282 However, the root lobes seem more robust in the Nigerian material. These teeth from

283 Awgu would confirm the occurrence of this species in the Late Cretaceous of Africa.

286 Incertae familiae

287 Incertae genus 
“Carcharias" amonensis (Cappetta and Case, 1975a)

$290 \quad$ (Fig. 3A)

291

292 Material examined. One tooth (GR/PC.1779).

293 Age and locality. Late Cenomanian (Gadeni Zone), Ashaka quarry (level 9>),

294 northeastern Nigeria.

295

296 Description. The specimen corresponds to an upper lateral tooth. The main cusp is

297 labiolingually compressed and strongly bent distally. There is one pair of triangular

298 lateral cusplets, plus one additional incipient mesial cusplet. The root is damaged and no

299 lingual protuberance, median furrow or lobes can be observed.

300

301 Remarks. This small tooth is clearly referable to "Carcharias" amonensis, a

302 geographically widespread Cenomanian lamniform shark. This taxon corresponds to a

303 good biostratigraphical marker for this stage. It is mainly known from North American

304 and European localities where it can be abundant, while it seems to be slightly less

305 common in Africa. In this continent, it has been found in Morocco (Cavin et al., 2010),

306 Libya (Rage and Cappetta 2002), Egypt (Slaughter and Thurmond, 1974; Werner,

307 1989), and Angola (Antunes and Cappetta, 2002). It is also present in Lebanon, where a

308 few complete skeletons have been collected (Cappetta, 2012: 208). This species is

309 clearly not an odontaspidid s.l. (e.g., Odontaspis, Carcharias, and their fossil relatives)

310 and is only assigned to the genus Carcharias pending further study on its relationships

311 to other lamniform sharks.

312 
314 Order RAJIFORMES Berg, 1940

315 Incertae familiae

316 Genus Rhombopterygia Cappetta, 1980b

317

318 Rhombopterygia zaborskii sp. nov.

319 (Fig. 3B-E)

320

321 Holotype. One anterior tooth (GR/PC.1780) (Fig. 3B).

322 Paratypes. Three anterolateral to lateral teeth (GR/PC.1781, GR/PC.1782,

323 GR/PC.1783) (Fig. 3C-E).

324 Additional material. Two incomplete teeth.

325 Age and type locality. Late Cenomanian (Gadeni Zone), Ashaka quarry (level 9>), 326 northeastern Nigeria.

327 Etymology. Species named in honour to Peter M. P. Zaborski, who led one of the author 328 (P.C.) to the Ashaka quarry.

329

330 Diagnosis. New species of Rhombopterygia with very small (about 0.5 to $0.8 \mathrm{~mm}$ wide) teeth characterized by the following features: 1) cusped crown at least as wide as root,

332 2) lingual face with concave lateral margins in occlusal view, 3) well-developed median 333 uvula, 4) lateral uvulae reduced but always present.

335 Differential diagnosis. New species of Rhombopterygia with teeth differing from those 336 of $R$. rajoides, the type and only species of the genus, by the following features: 1 ) 
337

338

340

341

342

343

344

346

347

348

349

350

351

352

353

354

355

356

357

358

359

360

anterior teeth narrower with crown as wide as root, 2) lateral margins of lingual face concave in anterior teeth, 3) median uvula narrower and less rounded, 4) more marked lateral uvulae, 5) cusp more developed in anterior teeth and present in lateralmost teeth, 6) smaller size.

Description. Anterior teeth (including the holotype GR/PC.1780: Fig. 3B) have a subrectangular crown in occlusal view. The labial edge of the crown is convex. The lingual face shows a well-developed, subtriangular median uvula that projects lingually, whereas lateral uvulae are much more reduced. Both faces are separated by a transverse crest that rises up into an obtuse central cusp. The root, not yery high, is as wide as the crown and shows in lingual view a pair of marginolingual foramina located below the junction of the median and lateral uvulae. In basal view, the root is marked by a deep median furrow that separates two subtriangular lobes. The furrow displays a foramen in central position. Lateral teeth (including the paratype GR/PC.1783: Fig. 3E) have a crown which is more expanded laterally and marked by a transverse crest bearing a lower central cusp. The lingual edge shows a broad, triangular central uvula which is flanked by one pair of smaller, poorly salient lateral uvulae. The root is narrower than the crown.

Remarks. Two "rhinobatoid" taxa have been described from the early Late Cretaceous of Africa. Isidobatus is a genus based on isolated "rhinobatoid"-like teeth from the late Cenomanian of Egypt (Werner, 1989). The Ashaka teeth do not display the transverse keels and crest present in those of Isidobatus and have less-developed median and lateral uvulae. They can thus be easily distinguished from this peculiar genus. The 
361 platyrhinid genus Tingitanius, recently described on the basis of a nearly complete

362 specimen from the early Turonian of Morocco (Claeson et al., 2013), has teeth which

363 are rather similar to those found at Ashaka. However, the teeth of Tingitanius mainly

364 differ by the lack of a cusp and their higher root.

365 The teeth from Ashaka are here assigned to the genus Rhombopterygia on the

366 basis of its broad crown, the shape of the transverse crest, the presence of a small cusp,

367 and the morphology of the lingual uvulae. This genus has been originally described on

368 the basis of complete skeletons from the Cenomanian of Lebanon representing a single

369 species, $R$. rajoides (Cappetta, 1980b). In addition, isolated teeth assigned to

370 Rhombopterygia have been reported from the Cenomanian and Coniacian of Spain

371 (Bernárdez, 2002; Vullo et al., 2009), while there is a doubtful occurrence from the

372 Campanian of Germany (Müller, 1989). The teeth described by Bernárdez (2002: pl. 54,

373 figs. 1-4) as " $R$. villae" (nomen nudum) strikingly resembles those of $R$. zaborskii sp.

374 nov. and are also late Cenomanian in age. Therefore, they might represent the same

375 species or closely related forms. Lastly, it can be noted that "Rhinobatos" whitfieldi

376 from the Cenomanian of Lebanon has similar teeth in overall morphology, but these are

377 smaller and more cuspidate (Cappetta, 1980b). Rhombopterygia was placed among the

378 Rhinobatidae by Cappetta (1980b, 2012), but the phylogenetic analysis performed by

379 Claeson et al. (2013) would not support this interpretation. This analysis found

380 "Rhinobatos" whitfieldi and Rhombopterygia rajoides as successive sister taxa to

381 Zanobatos and Myliobatiformes. However, it is worth noting that this result was

382 recovered by the $50 \%$ majority rule tree but not in the strict consensus.

383

384 
Genus Hamrabatis Cappetta, 1991

386

387 Hamrabatis sp.

388 (Fig. 3F, G)

389

390 Material examined. Two teeth (GR/PC.1784, GR/PC.1785).

391 Age and locality. Late Cenomanian (Gadeni Zone), Ashaka quarry (level 9>),

392 northeastern Nigeria.

393

394 Description. The best preserved specimen (GR/PC.1784: Fig. 3F) is a small

395 anterolateral tooth. In occlusal view, it displays a rhombic crown as wide as long and

396 marked by a blunt transverse keel. The lingual area of the occlusal face shows an

397 irregular, alveolate surface whereas the labial area is almost smooth. The lingual face is

398 strongly concave in profile view. The basal part of the lingual face is subhorizontal, flat

399 and falciform in occlusal view. The root is not preserved. A poorly preserved lateral

400 tooth (GR/PC.1785: Fig. 3G) shows a crown more expanded laterally. It is apparently

401 devoid of transverse keel and ornamentation. The basal part of the lingual face is

402 damaged.

403

404 Remarks. Hamrabatis is known from the Late Cretaceous of Europe, Northern Africa,

405 Near East and North America (see Cappetta, 2012). Thus, the presence of Hamrabatis

406 in the Cenomanian of Nigeria represents the southernmost occurrence of this

407 widespread rajiform genus. So far, H. bernardezi from France and Spain is the only

408 known Cenomanian species of the genus (Bernárdez, 2002; Vullo et al., 2007, 2009). 
409 The teeth from Ashaka differ from H. bernardezi by their crown almost devoid of

410 ornamentation, but this may be due to abrasion. Because of the scarcity and poor

411 preservation of the Ashaka material, these teeth are here referred to Hamrabatis sp. 412

414 Class OSTEICHTHYES Huxley, 1880

415 Order PYCNODONTIFORMES Berg, 1937

416 Family PYCNODONTIDAE Agassiz, 1833

417 Genus Acrotemnus Agassiz, 1836

418

419 Acrotemnus sp.

$420 \quad$ (Fig. 4A)

421

422 Material examined. One prearticular dentition (GR/PC.1786).

423 Age and locality. Early Turonian (Coloradoense Zone), Ashaka quarry (level 26), 424 northeastern Nigeria.

425

426 Description. The unique specimen corresponds to a large (92 $\mathrm{mm}$ long), complete right

427 prearticular dentition bearing 34 robust teeth. The symphysis is long $(52 \mathrm{~mm})$ but not

428 very thick. There are three rows of teeth. The ten teeth of the inner row are large, up to $42918 \mathrm{~mm}$ wide. They are bean-shaped or oblong and marked medially by a narrow

430 transverse groove. The twelve teeth of the middle row are less transversally extended

431 and are marked by a granular central depression. Lastly, the twelve teeth of the outer

432 row are oval to subcircular, with an unornamented, rounded central depression. 
434 Remarks. Macropycnodon is a large genus of pycnodont fish recently erected on the 435 basis of a single vomerine dentition (M. streckeri) and isolated teeth (M.

436 megafrendodon) from the Turonian of U.S.A. (Kansas and New Mexico, respectively)

437 (Shimada et al., 2010). Therefore, the prearticular dentition of Macropycnodon is

438 unknown and no direct comparisons can be made between the North American and the

439 Nigerian material. However, the dental features observed on the large prearticular jaw

440 from the Ashaka quarry are very similar to those present in Macropycnodon, especially

441 in the type species $M$. streckeri (specimen KUVP 946; Shimada et al., 2010: fig. 2). In

442 addition, the Nigerian specimen also shares with Macropycnodon the Turonian age and

443 the unusual large size. It can be distinguished from the prearticulars of the Coelodus

444 species, which bear teeth that are generally smooth and more elongated transversally

445 (Schultz and Paunović, 1997; Poyato-Ariza and Wenz, 2002: fig. 22a).

446 It is worth noting that some large pycnodont teeth and jaw fragments from the

447 Late Cretaceous (Turonian?) of the Damergou area in Niger (eastern Iullemmeden

448 Basin) have been referred by Arambourg and Joleaud (1943) to the poorly known taxon

449 Acrotemnus faba, originally described on the basis of a few associated teeth from the

450 Late Cretaceous (Turonian) of England (Agassiz, 1833-1843; Woodward, 1909). Like

451 Macropycnodon, this genus has robust teeth characterized by a sharp transverse apical

452 ridge (Arambourg and Joleaud, 1943: pl. II, figs. 14-17). Furthermore, some teeth from

453 Damergou show a ring-like ridge and a central depression (Arambourg and Joleaud,

454 1943: pl. II, figs. 11, 13), indicating that the variation in tooth morphology is similar to

455 that observed in Macropycnodon and the prearticular dentition from Ashaka. Since

456 Macropycnodon and Acrotemnus share the same diagnostic features, the former appears 
457 to be a junior synonym of the latter. Thus, Acrotemnus streckeri may be a subjective 458 junior synonym of $A$. faba, whereas A. megafrendodon is clearly a distinct species. The 459 Nigerian specimen here described is assigned to Acrotemnus sp. It must be noted that 460 two other Late Cretaceous species were referred to Acrotemnus: A. splendens from 461 Belgium (Leriche, 1911) and A. yangaensis from Angola (Dartevelle and Casier, 1949).

462 While the holotypic material of the former belongs in fact to the enigmatic, purported 463 pycnodontiform genus Hadrodus, the holotypic material (a single tooth) of the latter 464 must be regarded as Pycnodontidae indet.

465

466 Incerti ordinis (?PYCNODONTIFORMES Berg, 1937)

467 Incertae familiae

468 Genus "Stephanodus" Zittel, 1888

469

470 "Stephanodus" sp.

471 (Fig. 5A)

472

473 Material examined. Two teeth (including GR/PC.1787).

474 Age and locality. Late Cenomanian (Gadeni Zone), Ashaka quarry (level 9>), 475 northeastern Nigeria.

476

477 Description. This small hook-shaped branchial tooth shows a strong lateral 478 compression. A flattened discoid extension develops between the base and the hook. 479

480 Remarks. This dental morphotype is usually referred to the genus "Stephanodus", which 
481

482

483

484

485

486

487

488

489

490

491

492 Genus indet. A

493 (Fig. 4B, C)

494

495

496

497

498

499

500

501

502

503

504

\author{
(Fig. $4 \mathrm{~B}, \mathrm{C})$
}

may represent a parataxon (see discussion in Berreteaga et al., 2011). Such branchial teeth are mainly present in pycnodontiforms (Kriwet, 1999), but can also be found in other Mesozoic and Cenozoic fish groups. Thus, several authors considered "Stephanodus" as a non-pycnodontid fish and referred it to the Eotrigonodontidae within the Tetraodontiformes (e.g., Arambourg, 1952; Bardet et al., 2000; Dartevelle and Casier, 1949; White, 1934).

Order AMIIFORMES Hay, 1929

Family AMIIDAE Bonaparte, 1837

Subfamily VIDALAMIINAE Grande and Bemis, 1998

Material examined. Two vertebrae (GR/PC.1788-1789).

Age and locality. Latest Cenomanian (Gadeni Zone), Ashaka quarry (level 21>), northeastern Nigeria.

Description. The larger specimen (GR/PC.1788: Fig. 4B) corresponds to an abdominal vertebral centrum, slightly broader than high and weakly compressed anteroposteriorly.

It shows insubstantial parapophyses. The neural and aortal facets are visible dorsally and ventrally, respectively. In dorsoventral view, the smooth lateral surfaces appear markedly concave. The second, smaller specimen (GR/PC.1789: Fig. 4C) is a posterior caudal (ural) centrum, higher than wide. 
506 Remarks. The shape of these vertebral centra is characteristic of those found in the trunk

507 (= abdominal) and caudal region of amiid fishes (Grande and Bemis, 1998). The fact

508 that no well-developed parapophyses are fused to the centrum indicates that these

509 specimens do not belong to the subfamily Amiinae (Grande and Bemis, 1998). Based on

510 their general morphology, these two centra can be assigned to the subfamily

511 Vidalamiinae (Grande and Bemis, 1998). The dorsal vertebral centrum closely

512 resembles that of an indeterminate vidalamiine described from the Late Cretaceous

513 (Maastrichtian) of Brazil (Martinelli et al., 2013). However, the latter does not display

514 the concavity of the lateral surface observed in dorsoventral view in GR/PC.1788.

515 Among other mid-Cretaceous amiids, similar large centra characterized by a weak

516 anteroposterior compression are also observed in the Pachyamia from the late Albian of

517 Mexico (Grande and Bemis, 1998) and the early Cenomanian of the Near East (Chalifa

518 and Tchernov, 1982), as well as in a partial vertebral column of a possible indeterminate

519 vidalamiine from the middle Turonian of Brazil (Gallo et al., 2007b).

520

521 Genus indet. B

522 (Fig. 4D)

523

524 Material examined. One vertebra (GR/PC.1790).

525 Age and locality. Coniacian?-Santonian, Awgu, southeastern Nigeria.

526

527 Description. This specimen corresponds to a laterally extended vertebral centrum,

528 broader than high and anteroposteriorly compressed. No parapophyses are fused to the 
centrum. In anteroposterior view, it shows a subrhombic shape, with dorsolateral (i.e,

530 between the neural facets and parapophyses) and ventrolateral (i.e., between the aortal

531 facets and parapophyses) surfaces appearing slightly convex and concave, respectively.

532 This shape indicates a central trunk position.

533

534 Remarks. Like the amiid centra from the Ashaka quarry, this centrum shows anatomical

535 features that permit to assign it to the Vidalamiinae. However, it can be distinguished

536 from the Cenomanian abdominal vertebral centrum described above by a stronger

537 anteroposterior compression, a more rhombic outline, and the presence of slight

538 ventrolateral concavities. Thus, the material from Ashaka and Awgu may represent two

539 distinct vidalamiine taxa. Such ventrolateral concavities are an autapomorphic feature of

540 the non-marine (possibly marine?) genus Melvius from the Late Cretaceous

541 (Campanian-Maastrichtian) of North America (Bryant, 1987; Grande and Bemis,

542 1998), in which this character can be much more marked than in the centrum from

543 Ashaka. Unfortunately, the intracolumnar shape variation of the centra remains

544 unknown for the Ashaka vidalamiine, and a deeper comparison with Melvius is not

545 possible. Interestingly, the "early Senonian" (Coniacian-Santonian) locality of In

546 Beceten in southern Niger yielded an indeterminate amiid taxon (Broin et al., 1974). An

547 examination of the material (including isolated centra) housed at the Muséum national

548 d'Histoire naturelle of Paris indicates that the amiids from Awgu and In Beceten are at

549 least closely related (R.V. pers. observ.). It is worth noting that this specimen was

550 collected in the Awgu area beside a few teeth of the marine sharks Cretolamna and

551 Scapanorhynchus. However, all these fossils were found naturally cleaned on an

552 inclined outcrop surface, probably not exactly in situ. Furthermore, a different colouring 
553 also suggests that the amiid and shark specimens originally came from two distinct

554 beds.

555

556 Order IONOSCOPIFORMES Grande and Bemis, 1998

557 Family and genus indet.

558 (Fig. 5B)

559

560 Material examined. One tooth (GR/PC.1791).

561 Age and locality. Late Cenomanian (Gadeni Zone), Ashaka quarry (level 9>),

562 northeastern Nigeria.

563

564 Description. This small tooth shows a subcircular base, slight longitunal folds, and an

565 apex bearing a transverse, curved carina.

566

567 Remarks. This tooth resembles that described from the middle-late Cenomanian of

568 northern Spain (La Cabaña Formation) (Vullo et al., 2009), showing the typical

569 ionoscopiform dental features described by Mudroch and Thies (1996) and Thies and

570 Mudroch (1996). To date, ionoscopiform fishes are known from complete skeletons

571 from Middle Triassic to Early Cretaceous in Europe, Africa, and North and South

572 America (Alvarado-Ortega and Espinosa-Arrubarrena, 2008; Brito and Alvarado-

573 Ortega, 2008). However, Neorhombolepis, known from a single incomplete skeleton

574 from the Lower Chalk (Cenomanian) of England (Woodward, 1888), has been

575 considered by some authors as a ionoscopiform genus, closely related or even

576 synonymous to the ophiopsid genus Macrepistius from the Albian of Texas (Grande and 
577 Bemis, 1998; Patterson, 1973). In addition, it is noteworthy that the poorly known,

578 monospecific genus Petalopteryx from the Cenomanian of Lebanon (Pictet, 1850)

579 closely resembles the ophiopsid genera Teoichthys and Placidichthys (both from the

580 Early Cretaceous of America), and therefore may belong to this group of

581 ionoscopiforms. Lastly, the presence of some ionoscopiforms in the Cenomanian of

582 Komen (Slovenia) and the Island of Hvar (Croatia) was noted by Wenz and Kellner

583 (1986). All these data and observations would indicate that the temporal range of

584 ionoscopiforms fishes extends into the early Late Cretaceous, and thus would support

585 the assignment of the isolated teeth from the Cenomanian of Spain and Nigeria to this

586 primitive order of marine halecomorph fishes.

587

588

589 Order PACHYCORMIFORMES Berg, 1937

590 Family PACHYCORMIDAE Woodward, 1895

591 Genus Protosphyraena Leidy, 1860

592

593 cf. Protosphyraena sp.

$594 \quad$ (Fig. 4E)

595

596 Material examined. One incomplete tooth (GR/PC.1792).

597 Age and locality. Early Coniacian, Nkalagu, southeastern Nigeria.

598

599 Description. The crown is laterally compressed, not very elongated and triangular in

600 lateral view. The apex is broken, showing the very thin layer of enamel in cross-section. 
601 One of the two face displays a single, short enamel fold near the apex. There are two

602 sharp carinae. These anterior and posterior cutting edges are slightly concave and 603 convex, respectively.

604

605 Remarks. In Africa, the only report of this genus is a single tooth from the Maastrichtian 606 of Egypt (Gemmellaro, 1920), whereas it is widespread in the Cretaceous of North

607 America and Europe. More recently, a few isolated teeth from the Campanian-

608 Maastrichtian of Saudi Arabia were tentatively assigned to Protosphyraena sp. (Kear et 609 al., 2009).

610

611

612 Order CROSSOGNATHIFORMES Taverne, 1987

613 Suborder PACHYRHIZODONTOIDEI Forey, 1977

614 Family and genus indet.

615 (Fig. 6)

616

617 Material examined. One caudal skeleton (GR/PC.1793).

618 Age and locality. Late Cenomanian (Juddii Zone), Lokpanta (level 33), southeastern 619 Nigeria.

620

621 Description. The caudal skeleton is embedded at the surface of a flattened, laminated 622 calcareous nodule. About ten preural vertebrae are preserved. Most of the bones of the 623 caudal fin have been removed by weathering and are now preserved as external moulds.

624 There are two well-developed dorsal and ventral caudal scutes. These bones are curved, 
625 broaden medially and become thinner, needle-like at their extremities. Posteriormost 626 centra of the preural vertebrae are hardly visible, as well as the ural centra. The basal 627 (proximal) part of an element identified as the parhypural would indicate the position of 628 the first preural centrum (Pu1). Hypural elements seems to be largely fused $(\mathrm{Hy} 1+\mathrm{Hy} 2$ 629 and $\mathrm{Hy} 3+\mathrm{Hy} 4$ condition?). Uroneural elements are damaged, possibly displaced, but 630 rather large and broad element (Un1?) with a pointed distal extremity can be observed.

631 Imprints of lepidotrichs, of which the bases partly overlap the hypurals, indicate a 632 significant degree of hypurostegy. Although distal parts of the caudal fin lobes are not 633 preserved, the symmetry of the tail suggests that it may have been forked and 634 homocercal. The upper and lower lobes show eleven and nine principal rays, 635 respectively. Outermost rays are well segmented. Between these two lobes, the tail 636 displays numerous thin and densely segmented lepidotrichs.

638 Remarks. Despite its state of preservation, this specimen shows some anatomical 639 features (i.e., well-developed caudal scutes and uroneurals, partly fused hypurals) that 640 are present in most of pachyrhizodontoid fishes, such as Elopopsis, Goulminichthys and 641 Pachyrhizodus (Cavin, 2001: fig. 13). This group of primitive teleosts are well 642 represented in the early Late Cretaceous of Northern Africa, with Elopopsis and 643 Goulminichthys from the Cenomanian and Turonian of Morocco, respectively (Cavin, 644 1995, 2001; Taverne, 1976).

647 Order AULOPIFORMES Rosen, 1973

648 Family ENCHODONTIDAE Woodward, 1901 
649 Genus Enchodus Agassiz, 1835

650

651 Enchodus cf. gladiolus (Cope, 1872)

652 (Fig. 5C)

653

654 Material examined. Two teeth (including GR/PC.1794).

655 Age and locality. Late Cenomanian (Gadeni Zone), Ashaka quarry (level 9>),

656 northeastern Nigeria.

657

658 Description. The larger and best preserved tooth is sigmoid in lateral view and shows a

659 weak barb in the apical region of the posterior carina. In the posterior part of the crown,

660 there are a few longitudinal folds between the base and the barb.

661

662 Remarks. This tooth from Ashaka is very similar to those from the middle-late

663 Cenomanian of North America that are referred to Enchodus cf. gladiolus (Cumbaa et

664 al., 2010; Nagrodski et al,, 2012; Shimada et al., 2006). As mentioned above, Enchodus

665 (E. lamberti) was reported in Nigeria from the Yolde and Fika Shales formations by

666 Carter et al. (1963).

667

668

669 Order ALBULIFORMES Nelson, 1973

670 Family PHYLLODONTIDAE Sauvage, 1875

671 Genus Eodiaphyodus Dartevelle and Casier, 1949

672 
673 Eodiaphyodus cf. granulosus Arambourg, 1952

674 (Fig. 4F)

675

676 Material examined. One nearly complete tooth plate (GR/PC.1795).

677 Age and locality. Early Maastrichtian (Neubergicus Zone), Calabar, southeastern 678 Nigeria.

679

680 Description. This oval-shaped tooth plate (47 $\mathrm{mm}$ long and $37 \mathrm{~mm}$ wide) displays an 681 aggregation of numerous small subcircular teeth (between 2 and $4 \mathrm{~mm}$ in diameter). The 682 basal face of the plate shows the tooth bases which are thick, irregular and marked by a

683 central depression. The occlusal face of the plate is more convex and has a smooth 684 surface.

685

686 Remarks. This genus was originally described on the basis of complete and fragmentary

687 tooth plates from the Maastrichtian of the Democratic Republic of the Congo and 688 assigned to a new species, Eodiaphyodus lerichei (Dartevelle and Casier, 1949).

689 Arambourg (1952) described a second species (i.e., E. granulosus) from the

690 Maastrichtian (and Paleocene?) of Morocco. In addition, Arambourg (1952) recognized

691 a third species (i.e., E. bebianoi) that had been previously referred to the genus

692 Pseudoegertonia by Dartevelle and Casier (1949). This species was described on the 693 basis of a few isolated teeth and tooth plate fragments from the Paleocene of the 694 Democratic Republic of the Congo (Dartevelle and Casier, 1949). E. bebianoi might 695 represent a senior synonym of E. granulosus, but it is better to consider it as a nomen 696 dubium due to the incompleteness of the type material. Estes (1969) tentatively referred 
697 the Moroccan species to the genus Pseudoegertonia and restricted the genus

698 Eodiaphyodus to the species E. lerichei alone, but this interpretation is not followed

699 here. As noted by Arambourg (1952), tooth plates of E. lerichei differ from those of $E$.

700 granulosus (and E. bebianoi) by their teeth that are relatively smaller, more numerous

701 and more slender. In E. lerichei, tooth bases are thinner, more regular and more circular,

702 showing a well-developed central depression (Dartevelle and Casier, 1949: pl. 18, fig.

703 1d). The tooth plate from Calabar described here is morphologically very close to $E$.

704 granulosus, although about twice smaller, and is tentatively referred to this species. In

705 Africa, Eodiaphyodus also occurs in the late Campanian-Maastrichtian of Angola

706 (Antunes and Cappetta, 2002) and thus seems to have been a common component of

707 latest Cretaceous to earliest Paleogene ichthyofaunas present along the Atlantic margin.

708

709

710 4. Concluding remarks

711

712 In all studied localities, the fish material is generally scarce and poorly diverse,

713 mainly due to sampling bias. Nevertheless, most of these sites have yielded one or

714 several taxa that are recorded for the first time in this part of Africa. Thus, these new

715 occurrences have significant palaeobiogeographical implications. The seaway that

716 occupied intermittently the Benue Trough during transgressive episodes is known to

717 have played a key role in the dispersal of many fish groups (Cavin, 2008; Cavin et al.,

718 2012; Gallo et al., 2007a; Maisey, 2000; Martín-Abad and Poyato-Ariza, 2013) and

719 marine invertebrates (e.g., Courville et al., 1998; Gebhardt, 1999; Néraudeau and

720 Courville, 1997; Néraudeau and Mathey, 2000), especially because it provided a 
721 connection between the proto-South Atlantic and the Mediterranean Tethys (via the

722 trans-Saharan seaway) during both the early Late Cretaceous and late Late Cretaceous

723 intervals (e.g., Benkhelil, 1989; Néraudeau and Mathey, 2000; Reyment, 1980a, b;

724 Reyment and Dingle, 1987). The late Cenomanian fish material from Nigeria includes

725 taxa which probably dispersed from the southwestern Europe (Iberian Peninsula) and/or

726 southern Tethyan platforms (Morocco to Lebanon), such as "Carcharias" amonensis,

727 Rhombopterygia and Hamrabatis. Thus, "C." amonensis was able to reach the South

728 Atlantic (Angola), corresponding to its southernmost and only Southern Hemisphere

729 occurrence (see Kitamura, 2013: fig. 3). As underlined by Cavin (2008), the

730 biogeographical history of pachyrhizodontoid fishes is not well understood. The

731 Nigerian occurrence could have resulted from either a vicariant or dispersal event. The

732 similarity between the vidalamiine from the late Cenomanian of northeastern Nigeria

733 (as well as both closely related forms from the younger beds of southern Nigeria and

734 Niger) and members of this clade from the Late Cretaceous of North and South America

735 may be indicative of an Early Cretaceous vicariant event, like for the genera

736 Calamopleurus and Pachyamia (Cavin, 2008). However, although most of Late

737 Cretaceous amiid fishes are regarded as non-marine forms, some of these fossils can be

738 recovered from marine deposits, such as the material studied here and the possible

739 vidalamiine specimen described from the Turonian of the Sergipe Basin in northeastern

740 Brazil (Gallo et al., 2007b). If these fragmentary specimens were not washed into the

741 sea and actually correspond to marine forms, a trans-Atlantic dispersal during the early

742 Late Cretaceous cannot therefore be rejected.

743 The origin and dispersal history of Ptychodus decurrens remains unclear. Verma

744 et al. (2012) have suggested that it could have dispersed from Western Australia to 
745 Europe and North America via India or the South Atlantic. This species had a mid to

746 high-palaeolatitudinal distribution (Hoch, 1992; Verma et al., 2012) and its equatorial

747 occurrence in the early Turonian of southern Nigeria may have been due to episodically

748 colder sea water temperatures in this part of the Benue Trough directly connected to the

749 South Atlantic (Néraudeau and Mathey, 2000). Occurrences of this species in the

750 Cenomanian-earliest Turonian of North Africa (e.g., Tunisia, Morocco) would suggest

751 that it migrated southwards during the Turonian to reach the Lower Benue Trough

752 (Nigeria) and Benguela Basin (Angola) in the early and late Turonian, respectively.

753 Interestingly, $P$. decurrens was also reported in the early Turonian of the Sergipe Basin

754 (northeastern Brazil), then located in the northwestern margin of the proto-South

755 Atlantic, roughly at the same palaeolatitude as the Lower Benue Trough (Andrade,

756 2005; Carvalho and Gallo, 2002). Concerning the genus Acrotemnus, it might have

757 dispersed from European seas to the trans-Saharan seaway (Niger) and Benue Trough

758 (Nigeria), and also to the Western Interior Seaway (U.S.A.). A similar pattern of

759 dispersal has been recently proposed by Martín-Abad and Poyato-Ariza (2013) for

760

various Cenomanian-Turonian pycnodontid genera.

761 Scapanorhynchus texanus might have originated during the Turonian-Santonian

762 interval in the Afro-Arabian plate where it is relatively rare, known only by a few teeth

763 from Angola, Nigeria, and Jordan (Antunes and Cappetta, 2002; Mustafa, 2000;

764 Zalmout and Mustafa, 2001). During the Campanian-Maastrichtian interval, this

765 species seems to have been restricted to North America (Cappetta and Case, 1975b;

766 Case and Schwimmer, 1988; Welton and Farish, 1993) while it was apparently replaced

767 in Africa and Near East by S. rapax (Antunes and Cappetta, 2002; Bardet et al., 2000;

768 Quaas, 1902; Retzler et al., 2013). As discussed above, the presence of a vidalamiine 
769 fish in the Coniacian?-Santonian beds of Awgu can be the result of either vicariant or 770 dispersal events.

771 The few Campanian-Maastrichtian occurrences of Eodiaphyodus along the

772 South Atlantic coast (Angola, Nigeria) are the oldest ones known for the genus. This

773 suggests that Eodiaphyodus originated in this part of Africa and dispersed northwards

774 (via the Atlantic coast of Western Africa or via the trans-Saharan seaway) to reach

775 northwestern Africa, where it is especially common in the late Maastrichtian of

776 Morocco (Arambourg, 1952).

777

778 Acknowledgements

779

780 We are grateful to Peter M. P. Zaborski for his precious assistance during fieldtrips

781 between 1988 and 1991, as well as the Service Culturel de l'Ambassade de France

782 (Lagos) and Elf Petroleum Nigeria Limited (now Total E\&P Nigeria Limited) for their

783 financial and technical support. Lionel Cavin and Louis P. Taverne are thanked for the

784 discussion about the pachyrhizodontoid specimen. We also thank Ronan Allain and

785 Gaël Clément for accessing the palaeoichthyological collection of the Muséum national

786 d'Histoire naturelle of Paris, and Holger Gebhardt for providing additional sediment

787 samples from the Ashaka section. Guillaume Guinot and an anonymous reviewer are

788 thanked for their valuable comments.

789

790

$791 \quad$ References

792 
793 Agassiz, 1833-1843. Recherches sur les Poissons fossiles. Imprimerie de Petitpierre, $794 \quad$ Neuchâtel.

795 Alvarado-Ortega, J., Espinosa-Arrubarrena, L., 2008. A new genus of ionoscopiform 796 fish (Halecomorphi) from the Lower Cretaceous (Albian) lithographic limestones 797 of the Tlayúa Quarry, Puebla, Mexico. Journal of Paleontology 82, 163-175.

798 Andrade, E.J., 2005. Turonian inoceramids and biostratigraphy of the Sergipe Basin, 799 northeastern Brazil: an integrated study of the Votorantim and Nassau quarries.

$800 \quad$ Unpublished Ph.D. thesis, University of Heidelberg, Germany.

801 Antunes, M.T., Cappetta, H., 2002. Sélaciens du Crétacé (Albien-Maastrichtien)

802 d'Angola. Palaeontographica, Abteilung A 264, 85-146.

803 Arambourg, C., 1952. Les vertébrés fossiles des gisements de phosphates (Maroc804 Algérie - Tunisie). Notes et Mémoires du Service géologique du Maroc 92, 1$805 \quad 372$.

806 Arambourg, C., Joleaud, L., 1943. Vertébrés fossiles du Niger. Bulletin de la Direction 807 des Mines de l'Afrique Occidentale Française 7, 31-85.

808 Barber, W., 1958. Upper Cretaceous Mollusca from north-eastern Nigeria. Records of 809 the Geological Survey of Nigeria 1956, 14-37.

810 Bardet, N., Cappetta, H., Pereda Suberbiola, X., Mouty, M., Al Maleh, A.K., Ahmad, 811 A.M., Khrata, O., Gannoum, N., 2000. The marine vertebrate faunas from the 812 Late Cretaceous phosphates of Syria. Geological Magazine 137, 269-290.

813 Benkhelil, J., 1988. Structure et évolution géodynamique du bassin intracontinental de 814 la Bénoué (Nigéria). Bulletin des Centres de Recherches Exploration-Production $815 \quad$ Elf Aquitaine 12, 29-128.

816 Benkhelil, J., 1989. The origin and evolution of the Cretaceous Benue Trough (Nigeria). 
Journal of African Earth Sciences 8, 251-282.

818 Berg, L.S., 1937. A classification of fish-like vertebrates. Bulletin de l'Académie des 819 Sciences de l'U.R.S.S., Classe des Sciences mathématiques et naturelles (série 820 biologique) $1937,1277-1280$.

821 Berg, L.S., 1940. [Classification of fishes, both recent and fossil]. Travaux de l'Institut 822 Zoologique de l'Académie des Sciences de l'U.R.S.S. 5, 87-517. [in Russian]

823 Berg, L.S., 1958. System der rezenten und fossilen Fischartigen und Fische. VEB

824 Deutscher Verlag der Wissenschaften, Berlin.

825 Bernárdez, E., 2002. Los dientes de seláceos del Cretácico de la Depresión Central 826 Asturiana. Unpublished Ph.D. thesis, University of Oviedo, Spain.

827 Berreteaga, A., Poyato-Ariza, F.J., Pereda-Suberbiola, X., 2011. A new actinopterygian 828 fauna from the latest Cretaceous of Quintanilla la Ojada (Burgos, Spain). $829 \quad$ Geodiversitas 33, 285-301.

830 Bonaparte, C.L., 1832-1841. Iconografia della fauna italica per le quatro classi degli 831 animali vertebrati. Tipografia Salviucci, Roma.

832 Brito, P.M., Alvarado-Ortega, J., 2008. A new species of Placidichthys (Halecomorphi: 833 Ionoscopiformes) from the Lower Cretaceous Marizal Formation, northeastern 834 Brazil, with a review of the biogeographical distribution of the Ophiopsidae, in:

835 Cavin, L., Longbottom, A., Richter, M. (Eds.), Fishes and the Break-up of 836 Pangaea. Geological Society, London, Special Publications 295, pp. 145-154. 837 Broin, F. de, Buffetaut, E., Koeniguer, J.-C., Rage, J.-C., Russell, D., Taquet, P., 838 Vergnaud-Grazzini, C., Wenz, S., 1974. La faune de vertébrés continentaux du 839 gisement d'In Becetem (Sénonien du Niger). Comptes Rendus de l'Académie des $840 \quad$ Sciences, série D 279, 469-472. 
841 Bryant, L.J., 1987. A new genus and species of Amiidae (Holostei; Osteichthyes) from 842 the Late Cretaceous of North America, with comments on the phylogeny of the 843 Amiidae. Journal of Vertebrate Paleontology 7, 349-361.

844 Cappetta, H., 1980a. Modification du statut générique de quelques espèces de sélaciens $845 \quad$ crétacés et tertiaires. Palaeovertebrata 10, 29-42.

846 Cappetta, H., 1980b. Les sélaciens du Crétacé supérieur du Liban. II: Batoïdes.

847 Palaeontographica, Abteilung A 168, 149-229.

848 Cappetta, H., 1991. Découverte de nouvelles faunes de sélaciens (Neoselachii) dans les 849 phosphates maastrichtiens de la Mer Rouge, Egypte. Münchner

850 Geowissenschaftliche Abhandlungen, Reihe A 19, 17-56.

851 Cappetta, H., 2012. Chondrichthyes - Mesozoic and Cenozoic Elasmobranchii: Teeth, 852 in: Schultze, H.-P. (Ed.), Handbook of Paleoichthyology, volume 3E. Verlag Dr. 853 Friedrich Pfeil, München.

854 Cappetta, H., Case, G.R., 1975a. Sélaciens nouveaux du Crétacé du Texas. Geobios 8, $855 \quad 303-307$.

856 Cappetta, H., Case, G.R., 1975b. Contribution à l'étude des sélaciens du groupe 857 Monmouth (Campanien-Maestrichtien) du New Jersey. Palaeontographica, $858 \quad$ Abteilung A 151, 1-46.

859 Carter, J.D., Barber, D.F.M., Tait, E.A., 1963. The geology of parts of Adamawa, 860 Bauchi and Bornu Provinces, north-eastern Nigeria. Bulletin of the Geological 861 Survey of Nigeria 30, 1-109.

862 Carvalho, M.S.S. de, Gallo, V., 2002. The presence of Ptychodus (Chondrichthyes, 863 Hybodontoidea) in the Cotinguiba Formation, Upper Cretaceous of the Sergipe864 Alagoas Basin, northeastern Brazil, in: Castro, J.C. de, Dias-Brito, D., Musacchio, 
865

866

867

868

869

870

871

872

873

874

875

876

877

878

879

880

881

882

883

884

885

886

887

888

E.A., Rohn, R. (Eds.), Boletim do $6^{\circ}$ Simpóso sobre o Cretáceo do Brasil - $2^{\text {do }}$

Simposio sobre el Cretácico de América del Sur, São Pedro. UNESP publication, São Paulo, pp. 307-309.

Case, G.R., Schwimmer, D.R., 1988. Late Cretaceous fish from the Blufftown Formation (Campanian) in western Georgia. Journal of Paleontology 62, 290-301.

Casier, E., 1947. Constitution et évolution de la racine dentaire des Euselachii. II Etude comparative des types. Bulletin du Musée Royal d'Histoire Naturelle de Belgique 23, 1-32.

Cavin, L., 1995. Goulminichthys arambourgi n. g., n. sp., un Pachyrhizodontidae (Actinopterygii, Teleostei) d'une nouvelle localité à nodules fossilifères du Turonien inférieur marocain. Comptes Rendus de l'Académie des Sciences, série IIa 321, 1049-1054.

Cavin, L., 2001. Osteology and phylogenetic relationships of the teleost Goulminichthys arambourgi Cavin, 1995, from the Upper Cretaceous of Goulmima, Morocco. Eclogae geologica Helvetiae 94, 509-535.

Cavin, L., 2008. Palaeobiogeography of Cretaceous bony fishes (Actinistia, Dipnoi and Actinopterygii), in: Cavin, L., Longbottom, A., Richter, M. (Eds.), Fishes and the Break-up of Pangaea. Geological Society, London, Special Publications 295, pp. $165-183$.

Cavin, L., Alexopoulos, A., Piuz, A., 2012. Late Cretaceous (Maastrichtian) ray-finned fishes from the island of Gavdos, southern Greece, with comments on the evolutionary history of the aulopiform teleost Enchodus. Bulletin de la Société géologique de France 183, 561-572.

Cavin, L., Tong, H., Boudad, L., Meister, C., Piuz, A., Tabouelle, J., Aarab, M., Amiot, 

R., Buffetaut, E., Dyke, G., Hua, S., Le Lœuff, J., 2010. Vertebrate assemblages from the early Late Cretaceous of southeastern Morocco: An overview. Journal of $891 \quad$ African Earth Sciences 57, 391-412.

892 Chalifa, Y., Tchernov, E., 1982. Pachyamia latimaxillaris, new genus and species 893 (Actinopterygii: Amiidae), from the Cenomanian of Jerusalem. Journal of $894 \quad$ Vertebrate Paleontology 2, 269-285.

895 Claeson, K.M., Underwood, C.J., Ward, D.J., 2013. Tingitanius tenuimandibulus, a new 896 platyrhinid batoid from the Turonian (Cretaceous) of Morocco and the Cretaceous radiation of the Platyrhinidae. Journal of Vertebrate Paleontology 33, 1019-1036.

898 Cope, E.D., 1872. On the families of fishes of the Cretaceous formation in Kansas.

899 Proceedings of the American Philosophical Society 12, 327-357.

900 Courville, P., 1992. Les Vascoceratinae et les Pseudotissotiinae (Ammonitina)

901 d'Ashaka (NE Nigéria): relation avec leur environnement biosédimentaire.

902 Bulletin des Centres de Recherches Exploration-Production Elf Aquitaine 16, $903 \quad 407-457$.

904 Courville, P., 1993. Les formations marines et les faunes d'ammonites cénomaniennes

905 et turoniennes (Crétacé supérieur) dans le Fossé de la Bénoué (Nigéria). Impact

906 des facteurs locaux et globaux sur les échanges faunique à l'interface Téthys-

907 Atlantique Sud. Unpublished Ph.D. thesis, University of Dijon, France.

908 Courville, P., Lang, J., Thierry, J., 1998. Ammonite faunal exchanges between south 909 Tethyan platforms and South Atlantic during the Uppermost Cenomanian910 Lowermost/Middle Turonian in the Benue Trough (Nigeria). Geobios 31, 187911214.

912 Cumbaa, S.L., Shimada, K., Cook, T.D., 2010. Mid-Cenomanian vertebrate faunas of 
913

914

915

916

917

918

919

920

921

922

923

924

925

926

927

928

929

930

931

932

933

934

935

936

the Western Interior Seaway of North America and their evolutionary, paleobiogeographical, and paleoecological implications. Palaeogeography, Palaeoclimatology, Palaeoecology 295, 199-214.

Cuny, G., Martin, J.E., Sarr, R., 2012. A neoselachian shark fauna from the Late Cretaceous of Senegal. Cretaceous Research 34, 107-115.

Cuny, G., Ouaja, M., Srarfi, D., Schmitz, L., Buffetaut, E., Benton, M.J., 2004. Fossil sharks from the Early Cretaceous of Tunisia. Revue de Paléobiologie, volume spécial 9, 127-142.

Dartevelle, E., Casier, E., 1949. Les poissons fossiles du Bas-Congo et des régions voisines (deuxième partie). Annales du Musée du Congo Belge, série A 3, 201256.

Estes, R., 1969. Studies on fossil phyllodont fishes: interrelationships and evolution in the Phyllodontidae (Albuloidei). Copeia 2, 317-331.

Forey, P.L., 1977. The osteology of Notelops Woodward, Rhacolepis Agassiz and Pachyrhizodus Dixon (Pisces: Teleostei). Bulletin of the British Museum (Natural History) Geology 28, 123-204.

Gallo, V., Cavalcanti, M.J., Silva, H.M.A. da, 2007a. Track analysis of the marine palaeofauna from the Turonian (Late Cretaceous). Journal of Biogeography 34, $1167-1172$.

Gallo, V., Silva, H.M.A. da, Andrade, E.J., 2007b. New fish records from the Turonian of the Sergipe Basin, northeastern Brazil. Arquivos do Museu Nacional 65, 385396.

Gebhardt, H., 1997. Cenomanian to Turonian foraminifera from Ashaka (NE Nigeria): quantitative analysis and palaeoenvironmental interpretation. Cretaceous Research 
$18,17-36$.

938 Gebhardt, H., 1999. Cenomanian to Coniacian biogeography and migration of North 939 and West African ostracods. Cretaceous Research 20, 215-229.

940 Gemmellaro, M., 1920. Ittiodontoliti maëstrichtiani di Egitto. Atti della Reale

941 Accademia di Scienze, Lettere e Belle Arti di Palermo, $3^{\mathrm{a}}$ serie 11, 151-204.

942 Glikman, L.S., 1958. [Rates of evolution in lamnoid sharks]. Doklady Akademii Nauk

943 SSSR 123, 568-571. [in Russian]

944 Glikman, L.S., 1964. [Sharks of Paleogene and their stratigraphic significance]. Nauka

945 Press, Moscow-Leningrad. [in Russian]

946 Grande, L., Bemis, W.E., 1998. A comprehensive phylogenetic study of amiid fishes

947 (Amiidae) based on comparative skeletal anatomy. An empirical search for

948 interconnected patterns of natural history. Society of Vertebrate Paleontology

949 Memoir 4 (supplement to Journal of Vertebrate Paleontology 18), 1-690.

950 Guiraud, M., 1991. Mécanisme de formation du bassin sur décrochements multiples de

951 la Haute-Bénoué (Nigéria). Bulletin des Centres de Recherches Exploration-

$952 \quad$ Production Elf Aquitaine 15, 11-67.

953 Hay, O.P., 1929. Second bibliography and catalogue of the fossil Vertebrata of North

954 America - I. Carnegie Institute of Washington Publication 390, 1-917.

955 Herman, J., 1979. Réflexions sur la systématique des Galeoidei et sur les affinités du

956 genre Cetorhinus à l'occasion de la découverte d'éléments de la denture d'un

957 exemplaire fossile dans les sables du Kattendijk à Kallo (Pliocène inférieur,

958 Belgique). Annales de la Société Géologique de Belgique 102, 357-377.

959 Hoch, E., 1992. First Greenland record of the shark genus Ptychodus and the

960 biogeographic significance of its fossil assemblage. Palaeogeography, 
961 Palaeoclimatology, Palaeoecology 92, 277-281.

962 Huxley, T.H., 1880. On the application of the laws of evolution to the arrangement of

963 the Vertebrata, and more particularly to the Mammalia. Proceedings of the

964 Zoological Society of London 1880, 649-662.

965 Jaekel, O., 1898. Über die verschiedenen Rochentype. Sitzungsberichte der Gesellschaft

966 naturforschender Freunde zu Berlin 1898, 44-53.

967 Jordan, D.S., 1898. Description of a species of fish (Mitsukurinia owstoni) from Japan,

968 the type of a distinct family of lamnoid sharks. Proceedings of the California

$969 \quad$ Academy of Sciences, $3^{\text {rd }}$ series 1, 199-204.

970 Kear, B.P., Rich, T.H., Ali, M.A., Al-Mufarrih, Y.A., Matiri, A.H., Al-Masary, A.M.,

971 Attia, Y., 2009. An Upper Cretaceous (Campanian-Maastrichtian)

972 actinopterygian fish assemblage from the marginal marine Adaffa Formation of

$973 \quad$ Saudi Arabia. Cretaceous Research 30, 1164-1168.

974 Khalloufi, B., Ouarhache, D., Lelièvre, H., 2010. New paleontological and geological

975 data about Jbel Tselfat (Late Cretaceous of Morocco). Historical Biology 22, 57-

$976 \quad 70$.

977 Kitamura, N., 2013. "Carcharias" amonensis from the Upper Cretaceous Mifune Group

978 in Kumamoto, Japan. Paleontological Research 17, 230-235.

979 Kogbe, C.A., 1974. Palaeoecologic distribution of the vertebrate fossils in the

980 Dukamaje and Dange formations (Maestrichtian and Palaeocene) of north-western

981 Nigeria. Journal of Mining and Geology 8, 49-55.

982 Kriwet, J., 1999. Pycnodont fishes (Neopterygii, †Pycnodontiformes) from the Lower

983 Cretaceous of Uña (E-Spain) with comments on branchial teeth in pycnodontid

984 fishes, in: Arratia, G., Schultze, H.-P. (Eds.), Mesozoic Fishes - Systematics and 
985 Fossil Record. Verlag Dr. Friedrich Pfeil, München, pp. 215-238.

986 Leidy, J., 1860. Remarks on Saurocephalus and its allies. Transactions of the American 987 Philosophical Society (new series) 11, 91-95.

988 Leriche, M., 1911. Un pycnodontoïde aberrant du Sénonien du Hainaut - Le genre

989 Acrotemnus L. Agassiz - Acrotemnus splendens de Koninck. Bulletin de la

990 Société Belge de Géologie, de Paléontologie et d'Hydrologie 25, 162-168.

991 López-Arbarello, A., 2004. The record of Mesozoic fishes from Gondwana (excluding

992 India and Madagascar), in: Arratia, G., Tintori, A. (Eds.), Mesozoic Fishes 3 -

993 Systematics, Paleoenvironments and Biodiversity. Verlag Dr. Friedrich Pfeil, $994 \quad$ München, pp. 597-624.

995 Maisey, J.G., 2000. Continental break up and distribution of fishes of Western

996 Gondwana during the Early Cretaceous. Cretaceous Research 21, 281-314.

997 Martín-Abad, H., Poyato-Ariza, F.J., 2013. Historical patterns of distribution in

998 pycnodontiform and amiiform fishes in the context of moving plates. Geologica

$999 \quad$ Belgica 16, 217-226.

1000 Martinelli, A.G., Bogan, S., Agnolin, F.L., Ribeiro, L.C.B., Cavellani, C.L., Ferraz,

1001 M.L.F., Teixeira, V.P.A., 2013. First fossil record of amiid fishes (Halecomorphi,

1002 Amiiformes, Amiidae) from the Late Cretaceous of Uberaba, Minas Gerais State,

1003 Brazil. Alcheringa 37, 105-113.

1004 Meister, C., 1989. Les ammonites du Crétacé supérieur d'Ashaka, Nigéria: analyse

1005 taxonomique, ontogénétique, biostratigraphique et évolutive. Bulletin des Centres

1006 de Recherches Exploration-Production Elf Aquitaine 13, mémoire

1007 supplémentaire, 1-84.

1008 Mudroch, A., Thies, D., 1996. Knochenfischzähne (Osteichthyes, Actinopterygii) aus 
dem Oberjura (Kimmeridgium) des Langenbergs bei Oker (Norddeutschland).

$1010 \quad$ Geologica et Palaeontologica 30, 239-265.

1011 Müller, A., 1989. Selachier (Pisces: Neoselachii) aus dem höheren Campanium

1012 (Oberkreide) Westfalens (Nordrhein-Westfalen, NW-Deutschland). Geologie und

1013 Paläontologie in Westfalen 14, 1-161.

1014 Murray, A.M., 2000. The Palaeozoic, Mesozoic and Early Cenozoic fishes of Africa.

$1015 \quad$ Fish and Fisheries 1, 111-145.

1016 Mustafa, H., 2000. Fish teeth from the Upper Umm Ghudram Formation (Late

1017 Santonian) of NW-Jordan. Neues Jahrbuch für Geologie und Paläontologie,

$1018 \quad$ Monatshefte 2000, 595-612.

1019 Nagrodski, M., Shimada, K., Schumacher, B.A., 2012. Marine vertebrates from

1020 Hartland Shale (Upper Cretaceous: Upper Cenomanian) in southeastern Colorado,

$1021 \quad$ USA. Cretaceous Research 37, 76-88.

1022 Nelson, G.J., 1973. Relationships of clupeomorphs, with remarks on the structure of the

1023 lower jaw in fishes. Zoological Journal of the Linnean Society 53 (supplement 1),

$1024 \quad 333-349$.

1025 Néraudeau, D., Courville, P., 1997. Cenomanian and Turonian echinoids from Nigeria.

1026 Geobios 30, 835-847.

1027 Néraudeau, D., Mathey, B., 2000. Biogeography and diversity of South Atlantic

1028 Cretaceous echinoids: implications for circulation patterns. Palaeogeography,

1029 Palaeoclimatology, Palaeoecology 156, 71-88.

1030 Odunze, S.O., Stevens, N.J., Obi, G.C., Eastman, J.T., 2009. Paleocene ichthyofauna

1031 and paleoenvironmental setting, Imo Formation, southeastern Nigeria. Journal of

1032 Vertebrate Paleontology 29, supplement to 3, 158A. 
1033 Odunze, S.O., Stevens, N.J., Cooper, L.N., Obi, G.C., 2012. Paleogene ichthyofauna of

1034 the Imo and Ameki formations, southeastern Nigeria. Supplement to the online 1035 Journal of Vertebrate Paleontology 32, 152.

1036 Offodile, M.E., Reyment, R.A., 1977. Stratigraphy of the Keana-Awe area of the

1037 Middle Benue region of Nigeria. Bulletin of the Geological Institutions of the $1038 \quad$ University of Uppsala, New Series 7, 37-66.

1039 Patterson, C., 1966. British Wealden sharks. Bulletin of the British Museum (Natural

$1040 \quad$ History) Geology 11, 283-350.

1041 Patterson, C., 1973. Interrelationships of holosteans. Zoological Journal of the Linnean

$1042 \quad$ Society 53 (supplement 1), 233-305.

1043 Pervinquière, L. 1903. Etude géologique de la Tunisie centrale. Direction Générale des

1044 Travaux Publics, Carte géologique de la Tunisie, 1-359.

1045 Pictet, F.-J., 1850. Description de quelques poissons fossiles du Mont Liban. Imprimerie 1046 de Jules-Guillaume Fick, Genève.

1047 Poyato-Ariza, F.J., Wenz, S., 2002. A new insight into pycnodontiform fishes.

$1048 \quad$ Geodiversitas 24, 139-248.

1049 Quaas, A., 1902. Beitrag zur Kenntniss der Fauna der obersten Kreidebildungen in der 1050 libyschen Wüste (Overwegischichten und Blätterthone). Palaeontographica 30, $1051-153-336$.

1052 Rage, J.-C., Cappetta, H., 2002. Vertebrates from the Cenomanian, and the geological

1054 Retzler, A., Wilson, M.A., Avni, Y., 2013. Chondrichthyans from the Menuha

1055 Formation (Late Cretaceous: Santonian-Early Campanian) of the Makhtesh

1056 Ramon region, southern Israel. Cretaceous Research 40, 81-89. 
1057 Reyment, R.A., 1955. The Cretaceous Ammonoidea of southern Nigeria and the

1058 southern Cameroons. Bulletin of the Geological Survey of Nigeria 25, 1-112.

1059 Reyment, R.A., 1956. On the stratigraphy and palaeontology of Nigeria and the

1060 Cameroons, British West Africa. Geologiska Föreningen i Stockholm

$1061 \quad$ Förhandlingar 78, 17-96.

1062 Reyment, R.A., 1980a. Biogeography of the Saharan Cretaceous and Paleocene

1063 epicontinental transgressions. Cretaceous Research 1, 299-327.

1064 Reyment, R.A., 1980b. Paleo-oceanology and paleobiogeography of the Cretaceous

1065 South Atlantic Ocean. Oceanologica Acta 3, 127-133.

1066 Reyment, R.A., Dingle, R.V., 1987. Palaeogeography of Africa during the Cretaceous

1067 period. Palaeogeography, Palaeoclimatology, Palaeoecology 59, 93-116.

1068 Roemer, F., 1849. Texas. Mit besonderer Rücksicht auf deutsche Auswanderung und

1069 die physischen Verhältnisse des Landes nach eigener Beobachtung geschildert.

$1070 \quad$ Adolph Marcus, Bonn.

1071 Rosen, D.E., 1973. Interrelationships of higher euteleostean fishes. Zoological Journal

1072 of the Linnean Society 53 (supplement 1), 397-513.

1073 Sauvage, H.-E., 1875. Note sur le genre Nummulopalatus et sur les espèces de ce genre

1074 trouvées dans les terrains tertiaires de la France. Bulletin de la Société géologique

1075 de France, $3^{\text {ème }}$ série 3, 613-630.

1076 Schultz, O., Paunović, M., 1997. Der Nachweis von Coelodus (Osteichthyes,

1077 Pycnodontidae) im Turonien (Oberkreide) von Gams bei Hieflau, Steiermark,

1078 Österreich, und aus der Oberkreide von Kroatien und Italien. Annalen des

1079 Naturhistorischen Museums in Wien. Serie A für Mineralogie und Petrographie,

1080 Geologie und Paläontologie, Anthropologie und Prähistorie 98, 73-141. 
1081 Shimada, K., Schumacher, B.A., Parkin, J.A., Palermo, J.M., 2006. Fossil marine

1082 vertebrates from the lowermost Greenhorn Limestone (Upper Cretaceous: Middle

1083 Cenomanian) in southeastern Colorado. The Paleontological Society Memoir 63,

1084 supplement to Journal of Paleontology 80, 1-45.

1085 Shimada, K., Williamson, T.E., Sealey, P.L., 2010. A new gigantic pycnodont fish from

1086 the Juana Lopez Member of the Upper Cretaceous Mancos Shale of New Mexico,

1087 U.S.A. Journal of Vertebrate Paleontology 30, 598-603.

1088 Siverson, M., Lindgren, J., Newbrey, M.G., Cederström, P., Cook, T.D. Late Cretaceous

1089 (Cenomanian-Campanian) mid-latitude sharks of Cretalamna appendiculata type.

$1090 \quad$ Acta Palaeontologica Polonica, in press.

1091 Slaughter, B.H, Thurmond, J.T., 1974. A Lower Cenomanian (Cretaceous) ichthyofauna

1092 from the Bahariya Formation of Egypt. Annals of the Geological Survey of Egypt

$1093 \quad 4,25-40$.

1094 Stevens, N.J., Eastman, J.T., Odunze, S.O., Cooper, L.N., Obi, G.C., 2011. Paleocene

1095 ichthyofauna and paleoenvironmental setting, Imo Formation, southeastern

1096 Nigeria. Neues Jahrbuch für Geologie und Paläontologie, Abhandlungen 260,

$1097 \quad 289-296$.

1098 Taverne, L., 1976. A propos d'Elopopsis microdon, Heckel, J. J., 1856, du Crétacé

1099 moyen d'Afrique et d'Europe et des affinités systématiques de la famille fossile

1100 des Pachyrhizodontidae au sein des téléostéens primitifs. Revue Zoologique

$1101 \quad$ Africaine 90, 487-496.

1102 Taverne, L., 1987. On the cranial and caudal osteology of the Cretaceous marine teleost

1103 Pachyrhizodus (Pachyrhizodontidae, Crossognathiformes). Biologisch Jaarboek

$1104 \quad$ Dodonaea 55, 136-145. 
1105 Thies, D., Mudroch, A., 1996. Actinopterygian teeth from the Late Jurassic

1106 (Kimmeridgian) of N Germany, in: Arratia, G., Schultze, H.-P. (Eds.), Mesozoic

1107 Fishes - Systematics and Paleoecology. Verlag Dr. Friedrich Pfeil, München, pp.

$1108 \quad 105-114$.

1109 Verma, O., Prasad, G.V.R., Goswami, A., Parmar, V., 2012. Ptychodus decurrens

1110 Agassiz (Elasmobranchii: Ptychodontidae) from the Upper Cretaceous of India.

$1111 \quad$ Cretaceous Research 33, 183-188.

1112 Vullo, R., Cappetta, H., Néraudeau, D., 2007. New sharks and rays from the

1113 Cenomanian and Turonian of Charentes, France. Acta Palaeontologica Polonica

$1114 \quad 52,99-116$.

1115 Vullo, R., Bernárdez, E., Buscalioni, A.D., 2009. Vertebrates from the middle?-late

1116 Cenomanian La Cabaña Formation (Asturias, northern Spain):

1117 Palaeoenvironmental and palaeobiogeographic implications. Palaeogeography,

1118 Palaeoclimatology, Palaeoecology 276, 120-129.

1119 Welton, B.J., Farish, R.F., 1993. The Collector's Guide to Fossil Sharks and Rays from

1120 the Cretaceous of Texas. Before Time, Lewisvile, Texas.

1121 Wenz, S., Kellner, A.W.A., 1986. Découverte du premier Ionoscopidae (Pisces,

1122 Halecomorphi) sud-américain, Oshunia brevis n. g., n. sp., dans le Crétacé

1123 inférieur de la Chapada do Araripe (nord-est du Brésil). Bulletin du Muséum

1124 national d'Histoire naturelle, $4^{\text {ème }}$ série 8, 77-88.

1125 Werner, C., 1989. Die Elasmobranchier-Fauna des Gebel Dist Member der Bahariya

1126 Formation (Obercenoman) der Oase Bahariya, Ägypten. Palaeo Ichthyologica 5,

$1127 \quad 1-112$.

1128 White, E.I., 1926. Eocene fishes from Nigeria. Bulletin of the Geological Survey of 
Nigeria 10,1-82.

1130 White, E.I., 1934. Fossil fishes of Sokoto Province. Bulletin of the Geological Survey of $1131 \quad$ Nigeria 14, 1-78.

1132 White, E.I., 1955. Notes on African Tertiary sharks. Colonial Geology and Mineral $1133 \quad$ Resources 5, 319-325.

1134 Whitley, G.P., 1939. Taxonomic notes on sharks and rays. Australian Zoologist 9, 227262.

1136 Woods, H., 1911. The palaeontology of the Upper Cretaceous deposits of northern

1137 Nigeria, in: Falconer, J. D., The Geology and Geography of Northern Nigeria.

1138 Macmillan and Co., London, pp. 273-286.

1139 Woodward, A.S., 1888. A synopsis of the vertebrate fossils of the English chalk.

$1140 \quad$ Proceedings of the Geologists’ Association 10, 273-338.

1141 Woodward, A.S., 1889-1901. Catalogue of the Fossil Fishes in the British Museum

1142 (Natural History). Trustees of the British Museum of Natural History, Taylor and

$1143 \quad$ Francis, London.

1144 Woodward, A.S., 1909. The fossil fishes of the English chalk - Part 5. Monograph of

1145 the Palaeontological Society 63, 153-184.

1146 Zaborski, P.M.P., 1983. Campano-Maastrichtian ammonites, correlation and

1147 palaeogeography in southern Nigeria. Journal of African Earth Sciences 1, 59-63.

1148 Zaborski, P.M.P., 1985. Upper Cretaceous ammonites from the Calabar region, south-

1149 east Nigeria. Bulletin of the British Museum (Natural History) Geology Series 39, $1150 \quad 1-72$.

1151 Zaborski, P.M.P., 1987. Lower Turonian (Cretaceous) ammonites from south-east

1152 Nigeria. Bulletin of the British Museum (Natural History) Geology Series 41, 31- 
66.

1154 Zaborski, P.M.P., 1990a. The Cenomanian and Turonian (Mid-Cretaceous) ammonite

1155 biostratigraphy of north-eastern Nigeria. Bulletin of the British Museum (Natural

1156 History) Geology Series 46, 1-18.

1157 Zaborski, P.M.P., 1990b. Some Upper Cretaceous ammonites from southern Nigeria.

$1158 \quad$ Journal of African Earth Sciences 10, 565-581.

1159 Zalmout, I., Mustafa, H., 2001. A selachian fauna from the Late Cretaceous of Jordan.

$1160 \quad$ Yarmouk University Publications 10, 377-434.

1161 Zittel, K.A. von, 1888. Handbuch der Palæontologie. Abteilung I - Palæozoologie.

1162 Band III - Pisces, Amphibia, Reptilia, Aves. Druck und Verlag von R.

1163 Oldenbourg, München and Leipzig.

1164 
1166 Figure captions:

1167

1168 Fig. 1. Geographical and stratigraphical position of the fish remains studied here. A,

1169 Nigerian geographical framework (A1) and main Nigerian structural and sedimentary

1170 units (A2). B, synthetic stratigraphical successions of the Lower Benue Trough,

1171 southern Nigeria (B1) and Upper Benue Trough, northeastern Nigeria (B2). Map,

1172 stratigraphical successions and other data modified from Courville (1993) and Courville

1173 et al. (1998).

1174

1175 Fig. 2. A, Ptychodus decurrens, tooth (GR/PC.1773) in occlusal (A1), lingual (A2) and

1176 lateral (A3) views. B, cf. Protolamna sp., tooth (GR/PC.1774) in lingual (B1) and

1177 mesiodistal (B2) views. C, Cretolamna appendiculata, tooth (GR/PC.1775) in lingual

1178 (C1) and labial (C2) views. D, Squalicorax pristodontus, tooth (GR/PC.1776) in lingual

1179 (D1) and labial (D2) views. E, F, Scapanorhynchus cf. texanus, GR/PC.1777 (E) and

1180 GR/PC.1778 (F), teeth in lingual (E1, F), labial (E2) and distal (E3) views. Scale bars

1181 equal $5 \mathrm{~mm}(\mathrm{~B})$ and $10 \mathrm{~mm}(\mathrm{~A}, \mathrm{C}-\mathrm{F})$.

1182

1183 Fig. 3. A, "Carcharias" amonensis, tooth (GR/PC.1779) in lingual view. B-E,

1184 Rhombopterygia zaborskii sp. nov., holotype GR/PC.1780 (B), paratypes GR/PC.1781

1185 (C), GR/PC.1782 (D) and GR/PC.1783 (E), teeth in occlusal (B1, C, D1, E), lingual

1186 (B2, D2) and mesiodistal (B3) views. F, G, Hamrabatis sp., GR/PC.1784 (F) and

1187 GR/PC.1785 (G), teeth in occlusal (F1, G), lingual (F2) and mesiodistal (F3) views.

1188 Scale bars equal $500 \mu \mathrm{m}(\mathrm{B}-\mathrm{G})$ and $1 \mathrm{~mm}(\mathrm{~A})$. 
1190 Fig. 4. A, Acrotemnus sp., right prearticular dentition (GR/PC.1786) in occlusal view.

1191 B, C, Vidalamiinae indet. A, GR/PC.1788 (B) and GR/PC.1789 (C), abdominal and ural 1192 centra (respectively) in anterior (B1, C), posterior (B2), dorsal (B3), ventral (B4) and

1193 left lateral (B5) views. D, Vidalamiinae indet. B, abdominal centrum (GR/PC.1790) in

1194 anterior (D1), posterior (D2), dorsal (D3), ventral (D4) and left lateral (D5) views. E, cf.

1195 Protosphyraena sp., tooth (GR/PC.1792) in labiolingual views. F, Eodiaphyodus cf.

1196 granulosus, tooth plate (GR/PC.1795) in occlusal (F1), basal (F2) and lateral (F3)

1197 views. Scale bars equal 5mm (C, E) and $10 \mathrm{~mm}(\mathrm{~A}, \mathrm{~B}, \mathrm{D}, \mathrm{F})$.

1198

1199 Fig. 5. A, "Stephanodus" sp. (?Pycnodontiformes), branchial tooth (GR/PC.1787) in

1200 lateral view. B, Ionoscopiformes indet., tooth (GR/PC.1791) in mesiodistal? (B1),

1201 labial? (B2) and apical (B3) views. C, Enchodus cf. gladiolus, tooth (GR/PC.1794) in

1202 lateral view. Scale bars equal $500 \mu \mathrm{m}$.

1203

1204 Fig. 6. Pachyrhizodontoidei indet., caudal skeleton (GR/PC.1793) in right lateral view.

1205 Abbreviations: DCS, dorsal caudal spine; HS, hemal spine; Hy, hypural; Le,

1206 lepidotrichs; NS, neural spine; $\mathrm{Ph}$, parhypural, $\mathrm{Pu}$, preural vertebra; U, ural centrum;

1207 Un, uroneural; VCS, ventral caudal spine. Scale bar equals $50 \mathrm{~mm}$. 
Figure 1

ACCEPTED MANUSCRIPT

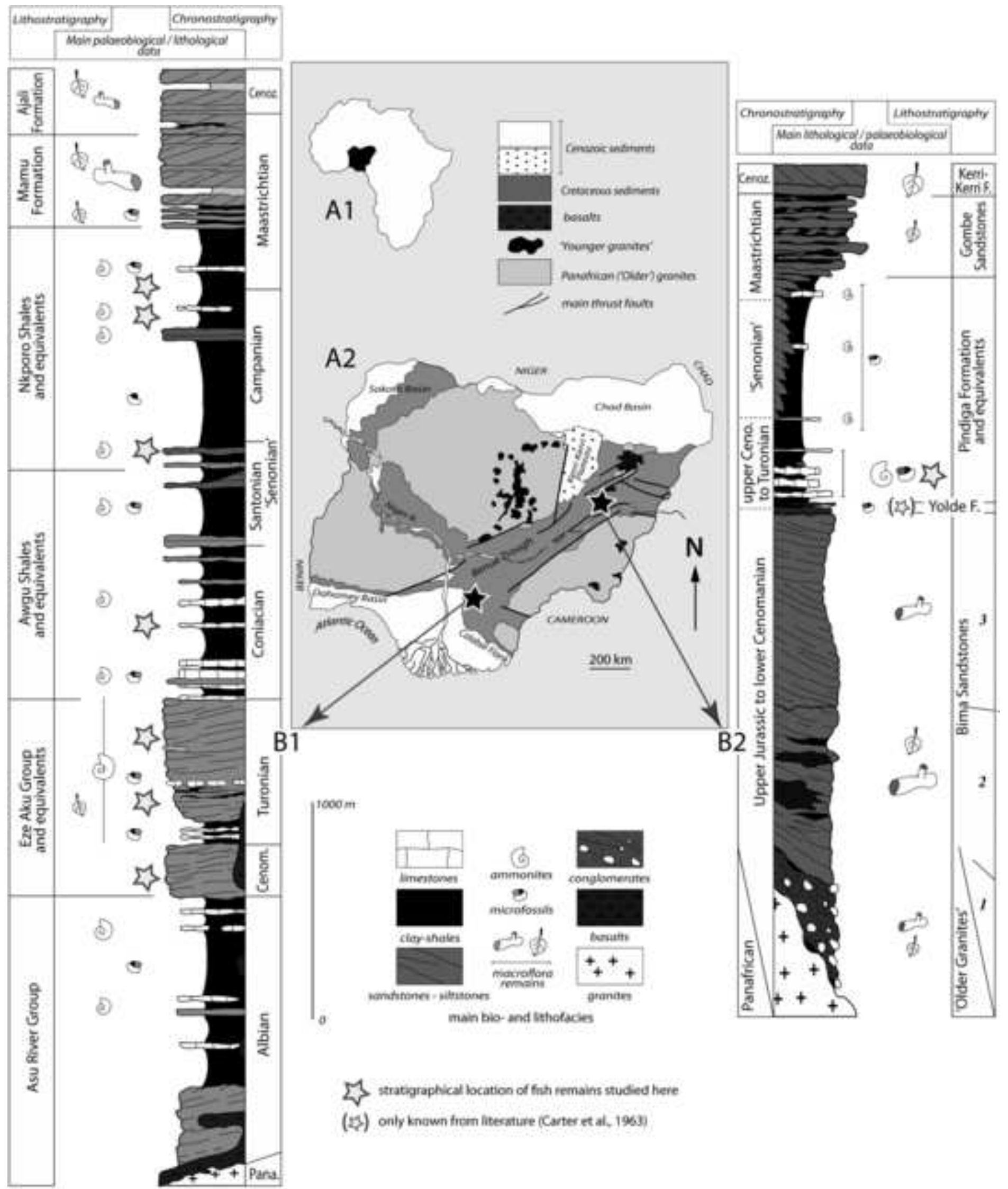




\section{ACCEPTED MANUSCRIPT}
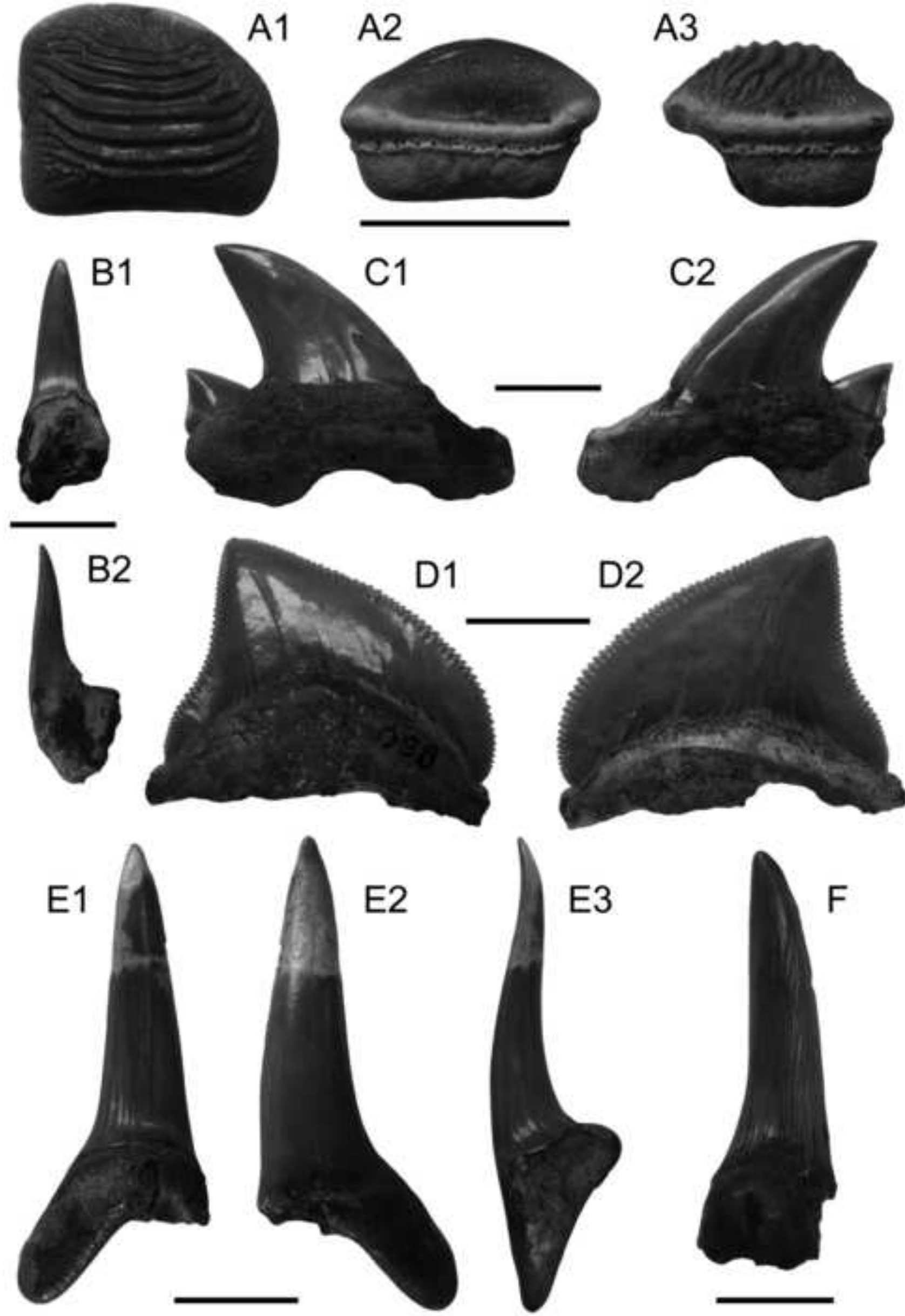


\section{ACCEPTED MANUSCRIPT}

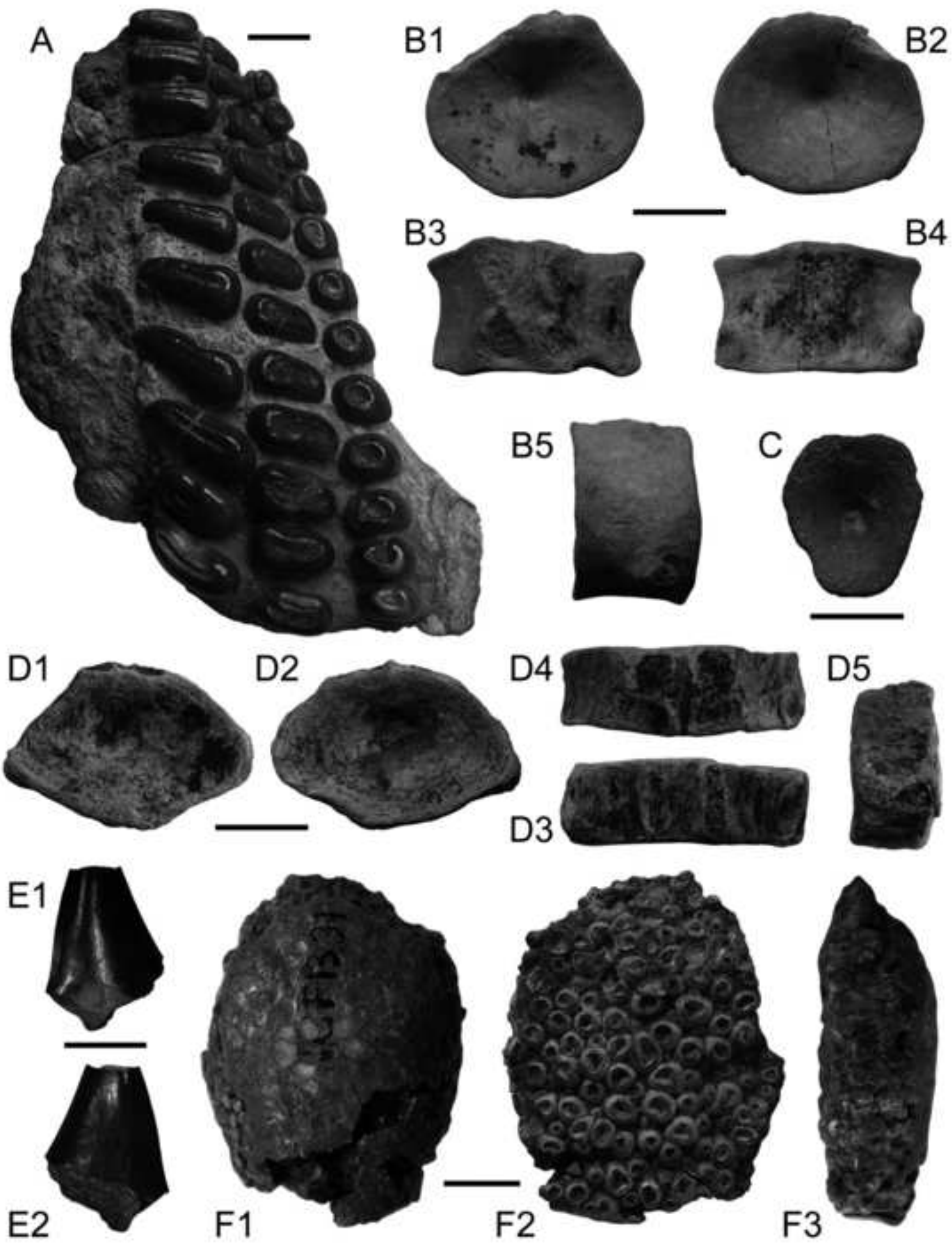



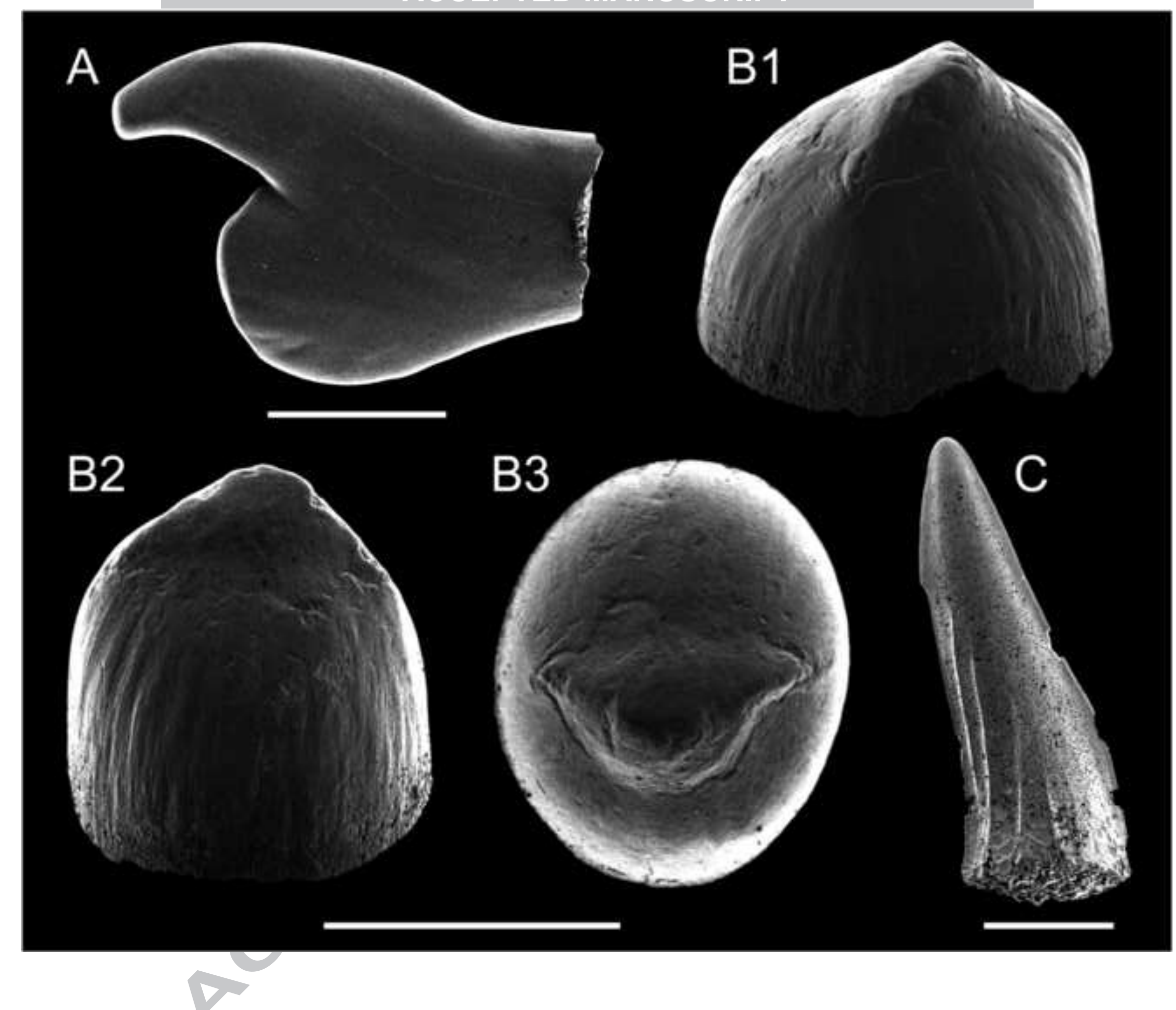

ACCEPTED MANUSCRIPT
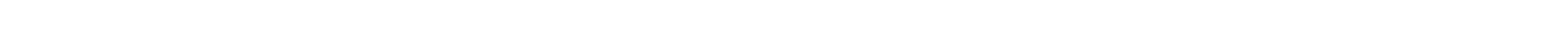


\section{ACCEPTED MANUSCRIPT}
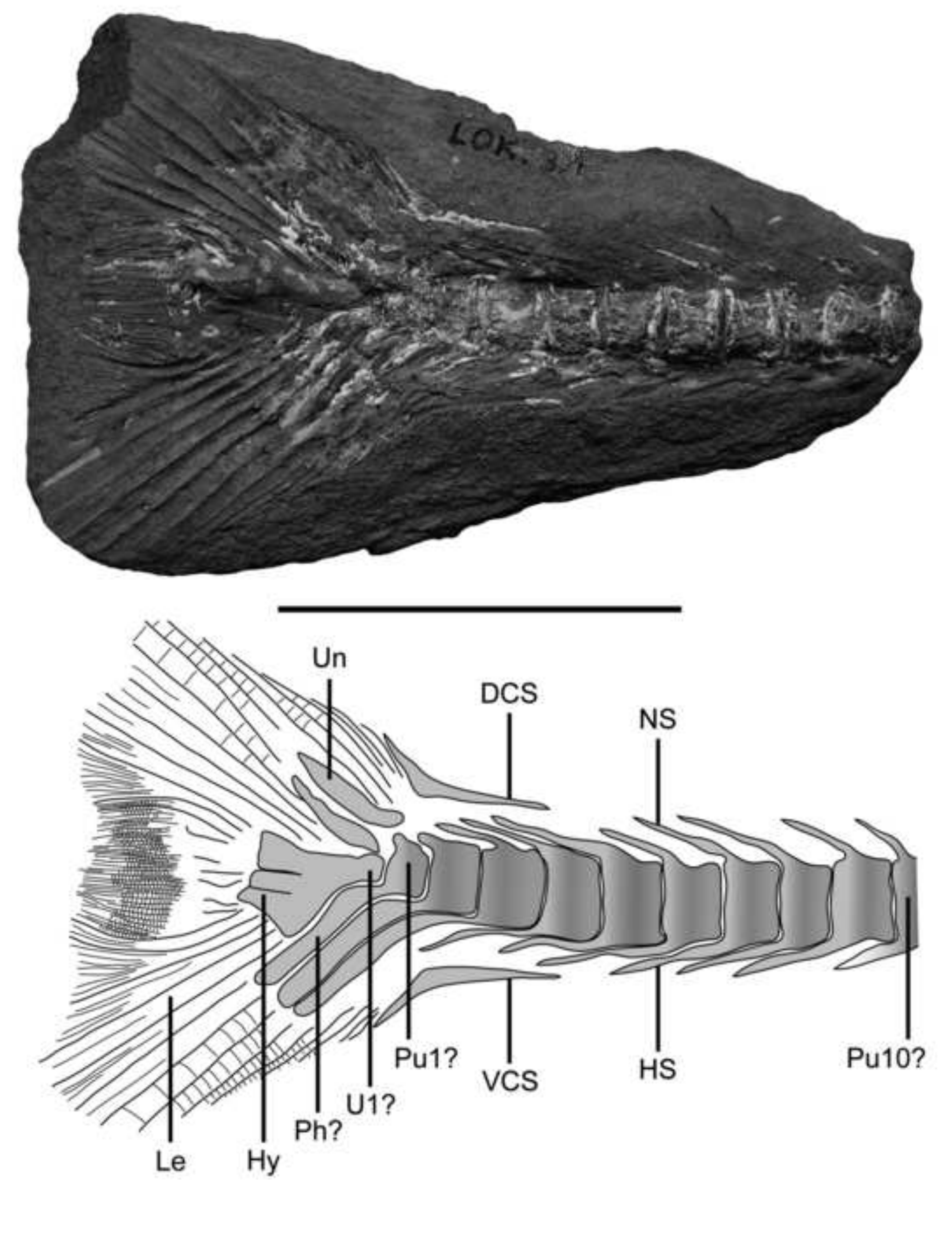

Figure 6
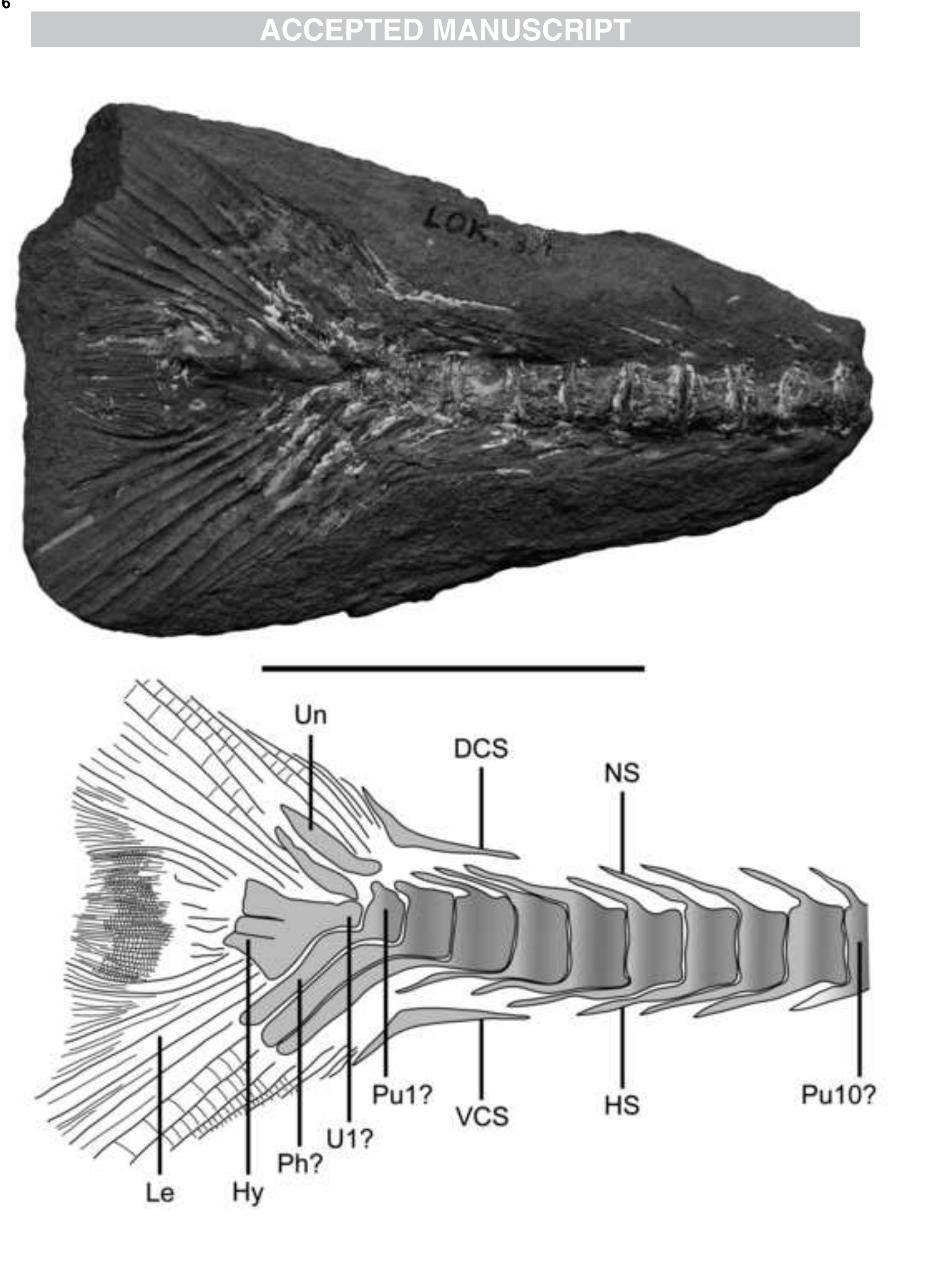

Figure 6$$
\text { . }
$$

.

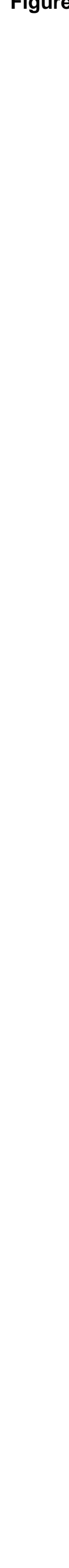

, 
1210 Highlights:

1211 - Selachian and ray-finned fishes are described from the Late Cretaceous of Nigeria.

1212 - Some fish taxa are recorded for the first time in Africa.

1213 - Rhombopterygia zaborskii sp. nov. is described from the Cenomanian of Ashaka.

1214 - The Benue Trough created opportunities for the dispersal of many marine fishes.

1215 